\title{
相互平均コンプライアンスによる構造音響連成系の時刻歴寄与解析
}

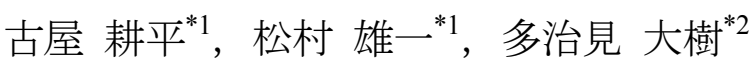

\section{Transient contribution analysis of vibro-acoustic system based on mutual mean compliance}

\author{
Kohei FURUYA ${ }^{* 1}$, Yuichi MATSUMURA*1 and Daiki TAJIMI ${ }^{* 2}$ \\ ${ }^{* 1}$ Department of Mechanical Engineering, Gifu University \\ 1-1 Yanagido, Gifu-shi, Gifu 501-1193 Japan \\ ${ }^{* 2}$ Graduate School of Engineering, Mechanical Systems Engineering Division, Gifu University \\ 1-1 Yanagido, Gifu-shi, Gifu 501-1193 Japan
}

\section{Received 27 November 2014}

\begin{abstract}
In this paper, time domain mutual mean compliance is proposed to reduce transient vehicle interior noise caused by discontinuous impact force from road surface. The interior noise is caused by coupling of structural vibration and acoustic modes. Therefore it is difficult to find an efficient design to attain light weight and comfortable interior noise performance. In frequency domain noise and vibration problem, by applying frequency domain mutual mean compliance to vibro-acoustic system, it is possible to separate the sound pressure into the contributions of structural system, acoustic system and coupling effect between structural systems and acoustic systems. Moreover mutual mean compliance shows not only contribution but also sensitivity of structural system, acoustic system and coupling effect, coincidently. Consequently, most sensitive part for reducing sound pressure without weight increase can be detected. In this paper, to reduce transient interior noise, mutual mean compliance was applied to time domain problem. The time domain mutual mean compliance can be calculated by using inverse fourier transform, but its application is restricted to linear system. To overcome the restriction, this paper presents a formulation of time domain mutual mean compliance based on central difference method that is a one of the numerical integration method. And it is shown theoretically that contribution and sensitivity of structural components to the transient interior noise can be evaluated by using proposed time domain mutual mean compliance. As an application, time domain mutual mean compliance is applied to a simple automobile body model and countermeasure for transient interior noise that attain light weight also is detected.
\end{abstract}

Key words : Sound and acoustic, Transient response, Sensitivity analysis, Contiribution analysis, Vibro-acoustic, Computer aided analysis, Finite element method

\section{1. 緒言}

自動車の車体開発では車室内の静肃化と燃費向上のための軽量化の両立が求められているままた経済発展が著 しい新興国では, 道路などのインフラ整備が十分でないため, 道路の突起を起振源とする過渡騒音が問題となる. 道路の突起による過渡騒音に対して，フーリエ変換やモード寄与率などを用い，構造系部品の寄与を把握し対策 した研究が報告されている（田中他，2013）。しかし，構造系だけではなく，音響系の寄与や構造系と音響系間の 連成の寄与など，騒音の発生メカニズムを把握し，これらを対策に結び付けた研究は見当たらない。

本研究では自動車の突起乗り越し時の過渡騒音を対策するために，任意の時刻の応答に対する構造系部品，音

No.14-00645 [DOI: 10.1299/transjsme.14-00645], J-STAGE Advance Publication date : 20 April, 2015

${ }^{* 1}$ 正員, 岐皁大学 工学部（广501-1193 岐阜県岐阜市柳戸 1-1）

*2 正員, 岐阜大学 大学院 工学研究科

E-mail of corresponding author: furuya@gifu-u.ac.jp 
響系, 構造系と音響系間の連成の寄与と感度を算出する数值解析法を提案する. 提案する方法は鶴見らが提案し た周波数領域での相互平均コンプライアンスを応用する方法である（鶴見他，2006）. 相互平均コンプライアンス は, 力が作用する点と振動を評価する点が異なる場合の二点間の柔軟性（コンプライアンス）を表す物理量で, 有限要素解析で各要素の相互平均コンプライアンスを求めることで, 二点間の柔軟性に対する各要素の寄与と感 度を把握できる (西脇他, 1997)。 また相互平均コンプライアンスの “相互” は力が作用する点と振動を評価する 点が異なることを意味し，それらが同じ点の場合，平均コンプライアンスと呼ばれ，静的問題では平均コンプラ イアンスはひずみエネルギの二倍と等しい. 周波数領域での相互平均コンプライアンスは, 周波数応答に対する 各部品の寄与と感度を示しており, 自動車室内のように構造系と音響系が連成する構造音響連成系の周波数領域 の問題で, 評価点応答に対する構造系部品, 音響系, 連成の寄与と感度を表すことを確認している (古屋他, 2014). 本研究では，ある物理量の和が着目寸る評価点応答と等しくなる量を寄与と呼ぶ. 構造系部品, 音響系, 連成の 相互平均コンプライアンスの和は評価点応答と等しくなることから, 相互平均コンプライアンスは寄与としての 性質を有する. 本稿では相互平均コンプライアンスを過渡騒音, すなわち時間領域の問題へ適用し, 任意の時刻 の応答に対する構造系部品, 音響系, 連成の寄与と感度を評価可能であることを示す．また相互平均コンプライ アンスに基づいた対策により，重量増加を抑えつつ時刻歴の音圧応答を低減する例を示寸。

本稿では中心差分に基づく数值積分法（以下，中心差分法）を用いて時間領域の相互平均コンプライアンスの 算出式を定式化する. 時間領域の相互平均コンプライアンスは, 周波数領域の相互平均コンプライアンスを逆フ ーリエ変換しても求まるが，この計算法では突起乗り越しの過程で系が線形性を保つという仮定が必要となり, 自動車のブッシュやサスペンションなどの非線形性を考慮するべき問題への適用が困難である. 一方, 相互平均 コンプライアンスを中心差分法で求めることで, それらの非線形性を考慮することも可能である.

本稿では第 2 章で周波数領域の相互平均コンプライアンスの概略を説明し, 第 3 章で時間領域の相互平均コン プライアンスを定式化する. 第 4 章では 6 自由度構造音響連成系モデルを用いて, 周波数領域と時間領域の相互 平均コンプライアンスの関係を具体的に示し, 時間領域の相互平均コンプライアンスの物理的な意味を確認する. また時間領域の相互平均コンプライアンスを中心差分法で求めることで, 系の非線形性も考慮できることを示す. 第 5 章では自動車の簡易車体モデルを対象として, 突起乗り越し時の任意の時刻の音圧応答に対する構造系部品, 音響系, 連成の寄与と感度を時間領域の相互平均コンプライアンスで把握し, 音圧低減と軽量化を両立できる効 率的な構造変更を提案可能であることを示す.

\section{2. 構造音響連成系の周波数領域の相互平均コンプライアンス}

本章では構造音響連成系の時間領域の相互平均コンプライアンスを定式化する準備として, 周波数領域の相互 平均コンプライアンス（鶴見他，2006）を構造音響連成系へ適用した際の相互平均コンプライアンスの物理的な 意味と，相互平均コンプライアンスが寄与と感度の性質を有することを説明する（古屋他，2014）。

\section{$2 \cdot 1$ 構造音響連成系の周波数領域の相互平均コンプライアンス}

本節では周波数領域の相互平均コンプライアンスを用いることで, 周波数応答に対する構造系部品, 音響系, 連成それぞれの寄与と感度を算出できることを説明する. 本稿では自動車の突起乗り越し時の音圧応答を対象と するため, 構造系と音響系が互いに影響を及ぼしあう構造音響連成系を対象とする. 構造音響連成系の周波数領 域の運動方程式は次式で表される.

$$
\left(\left[\begin{array}{cc}
\mathbf{K}_{\mathrm{S}} & \mathbf{A}_{\mathrm{SA}} \\
\mathbf{0} & \mathbf{K}_{\mathrm{A}}
\end{array}\right]+j \omega\left[\begin{array}{cc}
\mathbf{D}_{\mathrm{S}} & \mathbf{0} \\
\mathbf{0} & \mathbf{D}_{\mathrm{A}}
\end{array}\right]-\omega^{2}\left[\begin{array}{cc}
\mathbf{M}_{\mathrm{S}} & \mathbf{0} \\
-\mathbf{A}_{\mathrm{SA}}^{\mathrm{T}} & \mathbf{M}_{\mathrm{A}}
\end{array}\right]\right)\left\{\begin{array}{l}
\mathbf{x} \\
\mathbf{p}
\end{array}\right\}=\left\{\begin{array}{c}
\mathbf{f}_{\mathrm{S}} \\
\mathbf{f}_{\mathrm{A}}
\end{array}\right\}
$$

ここで $\mathbf{x}, \mathbf{p}, \mathbf{f}$ はそれぞれ変位，音圧，外力ベクトルを表し， M, K, D はそれぞれ質量, 剛性, 減衰行列, $\mathbf{A}_{\mathrm{SA}}$ は連成行列を表す. 連成行列は構造系と音響系の連成面の法線ベクトルと面積の積を表している. 下付き添え字 $\mathrm{S}$ は構造系，A は音響系を表している. 式（1）を展開すると次式を得る.

$$
\left(\mathbf{K}_{\mathrm{S}}+j \omega \mathbf{D}_{\mathrm{S}}-\omega^{2} \mathbf{M}_{\mathrm{S}}\right) \mathbf{x}=\mathbf{f}_{\mathrm{S}}-\mathbf{A}_{\mathrm{SA}} \mathbf{p}
$$




$$
\left(\mathbf{K}_{\mathrm{A}}+j \omega \mathbf{D}_{\mathrm{A}}-\omega^{2} \mathbf{M}_{\mathrm{A}}\right) \mathbf{p}=\mathbf{f}_{\mathrm{A}}-\omega^{2} \mathbf{A}_{\mathrm{SA}}^{\mathrm{T}} \mathbf{x}
$$

式 (2) は構造系の運動方程式である. 構造系には音響系の音圧による力 $\mathbf{A}_{\mathrm{SA}} \mathbf{p}$ が作用しており, 構造系単体とは 異なる連成系固有の振動形状になる，構造系が受ける音響系の音圧の影響を連成の影響と呼び，連成の影響が大 きいほど構造系単体の振動形状とは異なる振動形状になる. 同様に式 (3) は音響系の運動方程式である. 音響系 には構造系から体積加速度一 $\omega^{2} \mathbf{A}_{\mathrm{SA}}^{\mathrm{T}} \mathbf{x}$ が作用しており, 構造系の振動により音圧が発生する様子がわかる.

詳細は文献（古屋他，2014）に記載しているため本稿では詳しい導出を省略するが，振動と音圧を対象とした 場合の相互平均コンプライアンス $c_{x}(\omega), c_{p}(\omega)$ はそれぞれ次式で定義され, 評価点 $i$ の変位 $x_{i}(\omega)$, 音圧 $p_{i}(\omega)$ と等 しい值となる.

$$
\begin{aligned}
& x_{i}(\omega)=c_{x}(\omega)=\mathbf{y}^{\mathrm{T}}\left(\widetilde{\mathbf{K}}+j \omega \widetilde{\mathbf{D}}-\omega^{2} \widetilde{\mathbf{M}}\right)\left\{\frac{\begin{array}{c}
\mathbf{x} \\
\mathbf{p}
\end{array}}{j \omega}\right\}=\mathbf{y}^{\mathrm{T}}\left\{\begin{array}{c}
\mathbf{f}_{\mathrm{S}} \\
-\frac{\mathbf{f}_{\mathrm{A}}}{j \omega}
\end{array}\right\} \\
& p_{i}(\omega)=c_{p}(\omega)=j \omega \mathbf{y}^{\mathrm{T}}\left(\widetilde{\mathbf{K}}+j \omega \widetilde{\mathbf{D}}-\omega^{2} \widetilde{\mathbf{M}}\right)\left\{\frac{\begin{array}{c}
\mathbf{x} \\
\mathbf{p}
\end{array}}{j \omega}\right\}=j \omega \mathbf{y}^{\mathrm{T}}\left\{\begin{array}{c}
\mathbf{f}_{\mathrm{S}} \\
-\frac{\mathbf{f}_{\mathrm{A}}}{j \omega}
\end{array}\right\}
\end{aligned}
$$

ここで $\widetilde{\mathbf{K}} ， \widetilde{\mathbf{D}} ， \tilde{\mathbf{M}}$ は式（1）の特性行列を対称化した行列で，次式で表される.

$$
\widetilde{\mathbf{K}} \equiv\left[\begin{array}{cc}
\mathbf{K}_{\mathrm{S}} & \mathbf{0} \\
\mathbf{0} & -\mathbf{K}_{\mathrm{A}}
\end{array}\right], \quad \widetilde{\mathbf{D}} \equiv\left[\begin{array}{cc}
\mathbf{D}_{\mathrm{S}} & \mathbf{A}_{\mathrm{SA}} \\
\mathbf{A}_{\mathrm{SA}}^{\mathrm{T}} & -\mathbf{D}_{\mathrm{A}}
\end{array}\right], \quad \widetilde{\mathbf{M}} \equiv\left[\begin{array}{cc}
\mathbf{M}_{\mathrm{S}} & \mathbf{0} \\
\mathbf{0} & -\mathbf{M}_{\mathrm{A}}
\end{array}\right]
$$

また $\mathbf{y}, j \omega \mathbf{y}$ は各節点から評価点, 例えば運転者の耳位置の着目自由度 $i$ までの伝達関数を表しており, 次式で求 まる.

$$
\begin{aligned}
& \mathbf{y}=\left(\widetilde{\mathbf{K}}+j \omega \widetilde{\mathbf{D}}-\omega^{2} \widetilde{\mathbf{M}}\right)^{-1} \mathbf{g}_{i} \\
& \mathbf{g}_{i} \equiv\left[0, \cdots, 1_{\text {dof }=i}, \cdots 0\right]^{\mathrm{T}}
\end{aligned}
$$

$\mathbf{g}_{i}$ は評価点の着目自由度 $i$ の成分が 1 のベクトルであり随伴荷重と呼ぶ. 緒言で説明したように相互平均コンプ ライアンスの “相互” は，外力が作用する点と振動・音圧を評価する点が異なることを意味するが，より厳密に は外力 $\mathbf{f}$ と随伴荷重 $\mathbf{g}$ が異なることを意味し, 外力が作用する点と振動・音圧を評価する点が等しく, 外力が単 位力の場合, 外力 $\mathbf{f}=$ 随伴荷重 $\mathbf{g}$ となり, そのような場合, 相互平均コンプライアンスは平均コンプライアンスと 呼ばれる. 式 (4), (5) の右辺で表される相互平均コンプライアンス $c_{x}(\omega), c_{p}(\omega)$ は, 各節点から耳位置など評価 点の着目自由度 $i$ までの伝達関数 $\mathbf{y}, j \omega \mathbf{y}$ と, 各節点に生じている内力（特性行列と変位の積）の積で表されてい ることがわかる. 内力の総和は外力 $\mathbf{f}$ と等しいため, 相互平均コンプライアンス $c_{x}(\omega), c_{p}(\omega)$ は, 式（4）（5）の 最終式のように伝達関数 $\mathbf{y}$ と外力 $\mathbf{f}$ の積と考えることもできるが, 相互平均コンプライアンスを伝達関数と内力 の積と考え, 内力を構造系成分, 音響系成分, 連成の成分に分離することで各系の寄与が把握できる. 具体的に は, 式 (4)（5）の特性行列 $\widetilde{\mathbf{K}}, \widetilde{\mathbf{D}}, \tilde{\mathbf{M}}$ を構造系と音響系, 連成の成分に分離すると, 例えば式 (5) の音圧 $p_{i}(\omega)$ は次式のように構造系の内力 (特性行列) による成分 $c_{\mathrm{S}}$, 音響系の内力による成分 $c_{\mathrm{A}}$, 連成の影響による成分 $c_{\mathrm{Asa}}$ に分離できる.

$$
\begin{aligned}
& p_{i}(\omega)=c_{\mathrm{S}}(\omega)+c_{\mathrm{A}}(\omega)+c_{\mathrm{Asa}}(\omega) \\
& c_{\mathrm{S}}(\omega) \equiv j \omega \mathbf{y}^{\mathrm{T}}\left(\mathbf{K}_{\mathrm{S}}+j \omega \mathbf{D}_{\mathrm{S}}-\omega^{2} \mathbf{M}_{\mathrm{S}}\right) \mathbf{x}
\end{aligned}
$$




$$
\begin{aligned}
& c_{\mathrm{A}}(\omega) \equiv-j \omega \mathbf{y}^{\mathrm{T}}\left(\mathbf{K}_{\mathrm{A}}+j \omega \mathbf{D}_{\mathrm{A}}-\omega^{2} \mathbf{M}_{\mathrm{A}}\right) \frac{\mathbf{p}}{j \omega} \\
& c_{\mathrm{Asa}}(\omega) \equiv-\omega^{2} \mathbf{y}^{\mathrm{T}} \mathbf{A}_{\mathrm{SA}} \frac{\mathbf{p}}{j \omega}-\omega^{2} \mathbf{y}^{\mathrm{T}} \mathbf{A}_{\mathrm{SA}}^{\mathrm{T}} \mathbf{x}
\end{aligned}
$$

ここで $c_{\mathrm{S}}(\omega)$ を構造系の相互平均コンプライアンスと呼ぶ. 同様に $c_{\mathrm{A}}(\omega)$ を音響系, $c_{\mathrm{Asa}}(\omega)$ を連成の相互平均コン プライアンスと呼ぶ. 式（9）に示すように評価点の音圧 $p_{i}$ は構造系の相互平均コンプライアンス $c_{\mathrm{S}}$, 音響系の 相互平均コンプライアンス $c_{\mathrm{A}}$, 連成の相互平均コンプライアンス $c_{\mathrm{Asa}}$ の和で表されることから相互平均コンプラ イアンスは寄与としての性質を有する. また相互平均コンプライアンスの和が音圧と等しいことから, 相互平均 コンプライアンスは音圧と同じ次元を持つ. さらに構造系の剛性行列, 質量行列, 減衰行列は構造系を構成する 各部品の特性行列に分離できることから, 次式のように構造系の相互平均コンプライアンス $c_{\mathrm{S}}(\omega)$ を各部品の相互 平均コンプライアンス $c_{\mathrm{S}, j}(\omega)$ に分離できる.

$$
\begin{aligned}
& c_{\mathrm{S}}(\omega)=\sum_{j=1} c_{\mathrm{S}, j}(\omega) \\
& c_{\mathrm{S}, j}(\omega) \equiv j \omega \mathbf{y}^{\mathrm{T}}\left(\mathbf{K}_{\mathrm{S}, j}+j \omega \mathbf{D}_{\mathrm{S}, j}-\omega^{2} \mathbf{M}_{\mathrm{S}, j}\right) \mathbf{x}=j \omega \mathbf{y}^{\mathrm{T}} \mathbf{K}_{\mathrm{S}, j} \mathbf{x}-\omega^{2} \mathbf{y}^{\mathrm{T}} \mathbf{D}_{\mathrm{S}, j} \mathbf{x}-j \omega^{3} \mathbf{y}^{\mathrm{T}} \mathbf{M}_{\mathrm{S}, j} \mathbf{x}
\end{aligned}
$$

本式の部品 $j$ の相互平均コンプライアンス $c_{\mathrm{S}, j}(\omega)$ により, 音圧 $p_{i}$ に対する構造系の各部品の寄与を調べることが できる. さらに式 (14) に示すように $c_{\mathrm{S}, j}(\omega)$ を剛性, 減衰, 質量の各成分に分離することで, 寄与が大きいと特 定した部品が岡性として寄与しているのか, または質量として寄与しているのかなどの情報を得ることができる.

本節では音圧 $p_{i}$ に着目し相互平均コンプライアンスを説明したが，振動 $x_{i}$ に着目した場合も同様に，相互平均 コンプライアンスにより $x_{i}$ に対する構造系部品，音響系，連成の寄与を調べることができる．

\section{$2 \cdot 2$ 相互平均コンプライアンスと感度の関係}

本節では周波数領域の相互平均コンプライアンスと, 従来から利用されている板厚など, 構造系の設計変数の 変化に対する音圧の変化を表す音圧感度との関係を整理する. 構造系の部品 $j$ の設計変数 $\alpha_{j}$ の音圧 $p_{i}$ に対する感 度は, 対称化された構造音響連成系の運動方程式を設計変数 $\alpha_{j}$ で偏微分し, 感度 $\partial p_{i} / \partial \alpha_{j}$ について解くことで, 次 式のように求められる.

$$
\frac{\partial p_{i}(\omega)}{\partial \alpha_{j}}=-j \omega \mathbf{y}\left(\frac{\partial \mathbf{K}_{\mathrm{S}, j}}{\partial \alpha_{j}}+j \omega \frac{\partial \mathbf{D}_{\mathrm{S}, j}}{\partial \alpha_{j}}-\omega^{2} \frac{\partial \mathbf{M}_{\mathrm{S}, j}}{\partial \alpha_{j}}\right) \mathbf{x}
$$

本式の $\partial \mathbf{K}_{\mathrm{S}, j} / \partial \alpha_{j}, \partial \mathbf{D}_{\mathrm{S}, j} / \partial \alpha_{j}, \partial \mathbf{M}_{\mathrm{S}, j} / \partial \alpha_{j}$ は, 設計変数 $\alpha_{j}$ の変化に対する構造系の特性行列の変化を表している. 例 えば設計変数を板厚とした場合の音圧感度 $\partial p_{i} / \partial \alpha_{j}$ は, 板厚変化に対する特性行列の変化 $\partial \mathbf{K}_{\mathrm{s}, j} / \partial \alpha_{j}, \partial \mathbf{D}_{\mathrm{s}, j} / \partial \alpha_{j}$, $\partial \mathbf{M}_{\mathrm{s}, j} / \partial \alpha_{j}$ を有限要素解析やシェルの理論式から求め, 式 (15) へ代入することで求まる.

ここで抽象化された設計変数 $\alpha_{j}$ を考え, その設計変数 $\alpha_{j}$ を変更した後の特性行列 $\mathbf{K}_{\mathrm{S}, j}, \mathbf{D}_{\mathrm{S}, j}, \mathbf{M}_{\mathrm{S}, j}$ が, 構造 変更前の特性行列 $\mathbf{K}_{\mathrm{S}, j}, \mathbf{D}_{\mathrm{S}, j}, \mathbf{M}_{\mathrm{S}, j}$ と設計変数 $\alpha_{j}$ で次式のように表せると仮定する.

$$
\mathbf{K}_{\mathrm{S}, j}^{\prime}=\left(1+\alpha_{j}\right) \mathbf{K}_{\mathrm{S}, j}, \quad \mathbf{D}_{\mathrm{S}, j}^{\prime}=\left(1+\alpha_{j}\right) \mathbf{D}_{\mathrm{S}, j}, \quad \mathbf{M}_{\mathrm{S}, j}^{\prime}=\left(1+\alpha_{j}\right) \mathbf{M}_{\mathrm{S}, j}
$$

このとき $\partial \mathbf{K}_{\mathrm{S}, j}^{\prime} / \partial \alpha_{j}, \partial \mathbf{D}_{\mathrm{S}, j}^{\prime} / \partial \alpha_{j}, \partial \mathbf{M}_{\mathrm{S}, j}^{\prime} / \partial \alpha_{j}$ は次式で表される.

$$
\frac{\partial \mathbf{K}_{\mathrm{S}, j}^{\prime}}{\partial \alpha_{j}}=\mathbf{K}_{\mathrm{S}, j}, \quad \frac{\partial \mathbf{D}_{\mathrm{S}, j}^{\prime}}{\partial \alpha_{j}}=\mathbf{D}_{\mathrm{S}, j}, \quad \frac{\partial \mathbf{M}_{\mathrm{S}, j}^{\prime}}{\partial \alpha_{j}}=\mathbf{M}_{\mathrm{S}, j}
$$

式（17）を式（15）へ代入すると, 設計変数 $\alpha$ と特性行列の関係を式（16）と仮定したときの音圧感度が得られ, 次式の第一行で表される.

$$
\begin{aligned}
\frac{\partial p_{i}(\omega)}{\partial \alpha_{j}} & =-j \omega \mathbf{y}\left(\mathbf{K}_{\mathrm{S}, j}+j \omega \mathbf{D}_{\mathrm{S}, j}-\omega^{2} \mathbf{M}_{\mathrm{S}, j}\right) \mathbf{x} \\
& =-c_{\mathrm{S}, j}(\omega)
\end{aligned}
$$


本式の第一行の感度 $\partial p_{i} / \partial \alpha_{j}$ は式（14）で表される部品 $j$ の相互平均コンプライアンス $c_{\mathrm{S}, j}$ にー1 を乗じたものと 等しい. 寸なわち相互平均コンプライアンスは, 式 (16) のように設計変数 $\alpha$ の変化に対して特性行列が $\alpha$ 割変化 すると仮定したときの音圧感度に一1 を乗じたものと等しく, 相互平均コンプライアンスが大きい部位は音圧に 対する感度も高いことを示している.また本節の議論は振動 $x_{i}$ に着目した場合でも成立し, 振動 $x_{i}$ に着目した場合, 相互平均コンプライアンスは設計変数と特性行列の関係を式（16）と仮定したときの振動感度に一1 を乗じたも のと等しい.

以上のように相互平均コンプライアンスは, 設計変数 $\alpha$ の変化に対して特性行列が $\alpha$ 割変化すると仮定したとき の音圧感度, 振動感度に帰着し, かつ前節で説明したように寄与としての性質も有する. このように相互平均コ ンプライアンスは寄与と感度, 両方の性質を有するため, 設計変数を板厚や断面積とした従来の音圧感度, 振動 感度と比較して以下のような利点を有する.

・ 設計変数を板厚や断面積, 質量などとした従来の感度計算では, 次元の異なる感度を直接比較できないが, 相互平均コンプライアンスは音圧や振動など評価する応答と同じ次元を持つため, 剛性, 質量, 連成など次 元が異なるものの感度を単純比較できる.

・ 従来の感度計算では, 複数の部品の中でどの部品の感度が大きいかなど相対比較は容易であるが, 感度の絶 対值から音圧や振動への影響度を判断することが難しい. 一方, 相互平均コンプライアンスは, その和が評 価点応答と等しくなる寄与としての性質を有するため, 各部品の影響度を直感的に理解できる.

\section{3. 時間領域の相互平均コンプライアンスの導出}

本章では着目点応答に対する構造系, 音響系, 連成の寄与と感度の性質を有する相互平均コンプライアンスを, 突起乗り越しのような過渡騒音の対策で利用するために時間領域の相互平均コンプライアンスについて考える. 時間領域の相互平均コンプライアンスは, 周波数領域の相互平均コンプライアンスを逆フーリエ変換しても求ま るが，系の非線形性の考慮が難しいという問題が残る，そこで本章では中心差分に基づく数值積分法（以下，中 心差分法）を用いて時間領域の相互平均コンプライアンスの算出式を定式化する.

3.1 節では逆フーリエ变換を利用して時間領域の相互平均コンプライアンスを求める場合の説明を行い, 3.2 節 では中心差分法による時刻歴応答計算を説明する. そして 3.3 節で中心差分法を用いた時間領域の相互平均コン プライアンスの算出式を定式化する. さらに 3.4 節で, 時間領域の感度と時間領域の相互平均コンプライアンス を比較し, 時間領域の相互平均コンプライアンスが寄与と感度の両方の性質を有することを理論的に示す.

\section{$3 \cdot 1$ 逆フーリエ変換による時間領域の相互平均コンプライアンスの算出}

周波数領域から時間領域へ変換する最も簡単な方法は逆フーリエ变換を用いることであり, 先行研究でも周波 数領域の振動感度を時間領域の感度へ変換している(高野他, 2014). 式 (9) の周波数領域の音圧と相互平均コン プライアンスの関係式を逆フーリエ変換することで, 時間領域の相互平均コンプライアンスが次式のように求ま る.

$$
\begin{aligned}
& p_{i}(t)=c_{\mathrm{S}}(t)+c_{\mathrm{A}}(t)+c_{\mathrm{Asa}}(t) \\
& p_{i}(t)=\frac{1}{2 \pi} \int_{-\infty}^{\infty} p(\omega) e^{j \omega t} \mathrm{~d} \omega \\
& c_{\mathrm{S}}(t) \equiv \frac{1}{2 \pi} \int_{-\infty}^{\infty} c_{\mathrm{S}}(\omega) e^{j \omega t} \mathrm{~d} \omega \\
& c_{\mathrm{A}}(t) \equiv \frac{1}{2 \pi} \int_{-\infty}^{\infty} c_{\mathrm{A}}(\omega) e^{j \omega t} \mathrm{~d} \omega \\
& c_{\mathrm{Asa}}(t) \equiv \frac{1}{2 \pi} \int_{-\infty}^{\infty} c_{\mathrm{Asa}}(\omega) e^{j \omega t} \mathrm{~d} \omega
\end{aligned}
$$


式（19）が示すように時間領域の相互平均コンプライアンスの和は時間領域の音圧 $p_{i}(t)$ と等しい. 実際に時間領 域の相互平均コンプライアンスを求める場合, 離散逆フーリエ変換を行うことになる. 例えば, 式 (21) の $c_{\mathrm{S}}(t)$ を, 離散逆フーリエ変換で表すと次式のようになり, 周波数は離散化され, 積分区間も有限になる.

$$
c_{\mathrm{S}}\left(t_{n}\right)=\frac{1}{N} \sum_{k=-\frac{N}{2}}^{\frac{N}{2}} c_{\mathrm{S}}\left(\omega_{k}\right) \exp \left(j \frac{2 \pi k t_{n}}{N}\right)
$$

ここで $n$ は離散した時刻の番号, $k$ は離散した周波数の番号, $N$ はデータ点数を表す. 離散逆フーリエ変換の変 換誤差を小さくするためには周波数刻み $\Delta \omega=\omega_{k+1}-\omega_{k}$ を小さくし, 積分区間の上限周波数 $\omega_{N / 2}$ を大きくする必要 がある.

\section{$3 \cdot 2$ 中心差分法による時刻歴応答計算}

本節では中心差分法で構造音響連成系の時刻歴応答を算出する流れを説明する（MSC Software, 2013)。構造音 響連成系の時間領域の運動方程式は次式で表される.

$$
\left[\begin{array}{cc}
\mathbf{M}_{\mathrm{S}} & \mathbf{0} \\
-\mathbf{A}_{\mathrm{SA}}^{\mathrm{T}} & \mathbf{M}_{\mathrm{A}}
\end{array}\right]\left\{\begin{array}{l}
\ddot{\mathbf{x}} \\
\ddot{\mathbf{p}}
\end{array}\right\}+\left[\begin{array}{cc}
\mathbf{D}_{\mathrm{S}} & \mathbf{0} \\
\mathbf{0} & \mathbf{D}_{\mathrm{A}}
\end{array}\right]\left\{\begin{array}{c}
\dot{\mathbf{x}} \\
\dot{\mathbf{p}}
\end{array}\right\}+\left[\begin{array}{cc}
\mathbf{K}_{\mathrm{S}} & \mathbf{A}_{\mathrm{SA}} \\
\mathbf{0} & \mathbf{K}_{\mathrm{A}}
\end{array}\right]\left\{\begin{array}{l}
\mathbf{x} \\
\mathbf{p}
\end{array}\right\}=\left\{\begin{array}{c}
\mathbf{f}_{\mathrm{S}}(t) \\
\mathbf{f}_{\mathrm{A}}(t)
\end{array}\right\}
$$

本式を次式のように表す.

$$
\begin{aligned}
& \mathbf{M} \ddot{\chi}(t)+\mathbf{D} \dot{\chi}(t)+\mathbf{K} \chi(t)=\mathbf{f}(t) \\
& \mathbf{M} \equiv\left[\begin{array}{cc}
\mathbf{M}_{\mathrm{S}} & \mathbf{0} \\
-\mathbf{A}_{\mathrm{SA}}^{\mathrm{T}} & \mathbf{M}_{\mathrm{A}}
\end{array}\right], \quad \mathbf{D} \equiv\left[\begin{array}{cc}
\mathbf{D}_{\mathrm{S}} & \mathbf{0} \\
\mathbf{0} & \mathbf{D}_{\mathrm{A}}
\end{array}\right], \quad \mathbf{K} \equiv\left[\begin{array}{cc}
\mathbf{K}_{\mathrm{S}} & \mathbf{A}_{\mathrm{SA}} \\
\mathbf{0} & \mathbf{K}_{\mathrm{A}}
\end{array}\right], \quad \chi \equiv\left\{\begin{array}{l}
\mathbf{x} \\
\mathbf{p}
\end{array}\right\}, \quad \mathbf{f} \equiv\left\{\begin{array}{c}
\mathbf{f}_{\mathrm{S}} \\
\mathbf{f}_{\mathrm{A}}
\end{array}\right\}
\end{aligned}
$$

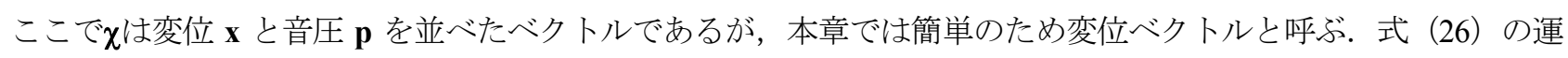
動方程式の未知変数は変位 $\chi$, 速度 $\dot{\chi}$, 加速度 $\ddot{\chi} の 3$ つである. 中心差分法では次式のように速度を変位の中心 差分で表し，加速度を速度の中心差分で表す。

$$
\begin{aligned}
& \dot{\chi}_{n}=\frac{1}{2 \Delta t}\left(\chi_{n+1}-\chi_{n-1}\right) \\
& \ddot{\chi}_{n}=\frac{1}{2 \Delta t}\left(\dot{\chi}_{n+1}-\dot{\chi}_{n-1}\right)=\frac{1}{\Delta t^{2}}\left(\chi_{n+1}-2 \chi_{n}+\chi_{n-1}\right)
\end{aligned}
$$

ここで $\Delta t=t_{n+1}-t_{n}$ は時間刻みを表し, 添え字 $n$ は計算ステップを表す. また変位, 外力は次式のように計算ステ ップ $n-1, n, n+1$ で平均化したものとする.

$$
\begin{aligned}
& \chi_{n}=\frac{1}{3}\left(\chi_{n+1}+\chi_{n}+\chi_{n-1}\right) \\
& \mathbf{f}_{n}=\frac{1}{3}\left(\mathbf{f}_{n+1}+\mathbf{f}_{n}+\mathbf{f}_{n-1}\right)
\end{aligned}
$$

以下では計算ステップ $n-1, n$ の変位 $\chi_{n-1}, \chi_{n}$ から計算ステップ $n+1$ の変位 $\chi_{n+1}$ を求める流れを説明する. 式 (27) から（30）を式（26）の運動方程式一代入すると次式を得る.

$$
\frac{\mathbf{M}}{\Delta t^{2}}\left(\chi_{n+1}-2 \chi_{n}+\chi_{n-1}\right)+\frac{\mathbf{D}}{2 \Delta t}\left(\chi_{n+1}-\chi_{n-1}\right)+\frac{\mathbf{K}}{3}\left(\chi_{n+1}+\chi_{n}+\chi_{n-1}\right) \mathbf{x}=\frac{1}{3}\left(\mathbf{f}_{n+1}+\mathbf{f}_{n}+\mathbf{f}_{n-1}\right)
$$

本式を整理すると次式を得る.

$$
\mathbf{A}_{1} \chi_{n+1}=\mathbf{a}_{2}+\mathbf{A}_{3} \chi_{n}+\mathbf{A}_{4} \chi_{n-1}
$$


ここで

$$
\mathbf{A}_{1} \equiv\left(\frac{\mathbf{M}}{\Delta t^{2}}+\frac{\mathbf{D}}{2 \Delta t}+\frac{\mathbf{K}}{3}\right), \quad \mathbf{a}_{2} \equiv \frac{1}{3}\left(\mathbf{f}_{n+1}+\mathbf{f}_{n}+\mathbf{f}_{n-1}\right), \quad \mathbf{A}_{3} \equiv\left(2 \frac{\mathbf{M}}{\Delta t^{2}}-\frac{\mathbf{K}}{3}\right), \quad \mathbf{A}_{4} \equiv\left(-\frac{\mathbf{M}}{\Delta t^{2}}+\frac{\mathbf{D}}{2 \Delta t}-\frac{\mathbf{K}}{3}\right)
$$

式（33）が示すように $\mathbf{A}_{1}, \mathbf{A}_{3}, \mathbf{A}_{4}$ は特性行列の和であり， $\mathbf{a}_{2}$ は外力の平均值である. 式（32）は，式（26）で 表される運動方程式を時間方向に離散化し, 計算ステップ $n+1$ の未知変位 $\chi_{n+1}$ に関連した項を左辺にまとめ, 既 知変数を右辺にまとめた運動方程式と考えることができる. また式（32）を，外力を表す $\mathbf{a}_{2}$ を左辺に置き整理し た場合は次式となり，本式は外力 $\mathbf{a}_{2}$ と内力のつり合いを表していると考えることができる.

$$
\mathbf{a}_{2}=\mathbf{A}_{1} \chi_{n+1}-\mathbf{A}_{3} \chi_{n}-\mathbf{A}_{4} \chi_{n-1}
$$

式（32）を未知変位 $\chi_{n+1}$ について解くと次式を得る.

$$
\chi_{n+1}=\mathbf{A}_{1}^{-1}\left(\mathbf{a}_{2}+\mathbf{A}_{3} \boldsymbol{\chi}_{n}+\mathbf{A}_{4} \boldsymbol{\chi}_{n-1}\right)
$$

時刻 $t=0$ (計算ステップ $n=0)$ における変位 $\chi_{n}$ は初期変位 $\chi_{0}$ で与えられ, 変位 $\chi_{n-1}$ は初期変位 $\chi_{0}$ と初期速度 $\dot{\chi}_{0}$ から 次式のように求まる.

$$
\left.\chi_{n-1}\right|_{n=0}=\chi_{0}-\dot{\chi}_{0} \Delta t
$$

これらの初期条件と式（35）を利用することで変位 $\chi_{n-1}, \chi_{n}$ から，変位 $\chi_{n+1}$ が求まる.

\section{$3 \cdot 3$ 中心差分法による時間領域の相互平均コンプライアンスの算出}

本節では中心差分法で求めた変位 $\chi_{n+1}$ を利用し, 時間領域の相互平均コンプライアンスを算出する. 前節で説 明したように時刻 $n+1$ の変位 $\chi_{n+1}$ は式 (35) で表される. 変位 $\chi_{n+1}$ は系全体の自由度を含んだべクトルである.こ こで振動・音圧を評価する点を $i$ とすると, $i$ 点の時刻 $n+1$ の変位 $\chi_{i}\left(t_{n+1}\right)$ は, 式 (8) の随伴荷重 $\mathbf{g}_{i}$ の転置を式 (35) の左から乗じることで次式のように求まる.

$$
\begin{aligned}
& \chi_{i}\left(t_{n+1}\right)=\mathbf{g}_{i}^{\mathrm{T}} \chi_{n+1}=\mathbf{y}^{\mathrm{T}}\left(\mathbf{a}_{2}+\mathbf{A}_{3} \boldsymbol{\chi}_{n}+\mathbf{A}_{4} \boldsymbol{\chi}_{n-1}\right) \\
& \mathbf{y} \equiv \mathbf{A}_{1}^{-\mathrm{T}} \mathbf{g}_{i} \\
& c\left(t_{n+1}\right) \equiv \mathbf{y}^{\mathrm{T}}\left(\mathbf{a}_{2}+\mathbf{A}_{3} \boldsymbol{\chi}_{n}+\mathbf{A}_{4} \boldsymbol{\chi}_{n-1}\right)
\end{aligned}
$$

ここで上付き添え字一 $\mathrm{T}$ は転置行列の逆行列を表す．式（38）は周波数領域の相互平均コンプライアンスの導出 で利用した式（7）に相当する. 本研究では, 式 (37) の右辺を時間領域の相互平均コンプライアンス $c\left(t_{n+1}\right)$ と定 義する (式 (39)) . 時間領域の相互平均コンプライアンス $c\left(t_{n+1}\right)$ は, 式 (4)（5）の周波数領域の相互平均コンプ ライアンスと同様に, 式（38）で表される $\mathbf{y}$ と力を表す $\mathbf{a}_{2}+\mathbf{A}_{3} \chi_{n}+\mathbf{A}_{4} \chi_{n-1}$ の積で表されている. 時間領域の $\mathbf{y}$ の物 理的な意味については議論の余地が残るが，4 章の適用例で示すように, 式（39）で定義した時間領域の相互平 均コンプライアンスと, 周波数領域の相互平均コンプライアンスを逆フーリエ変換したものは数值的に一致する. 周波数領域の相互平均コンプライアンスは着目自由度までの伝達関数と内力の積で表されていることから, 時間 領域の相互平均コンプライアンスもまた, 着目自由度までの伝達関数と内力の積を時間領域に変換したものであ ると考えられる.

次に時間領域の相互平均コンプライアンス $c\left(t_{n+1}\right)$ を構造系, 音響系, 連成の成分に分離することを考える. 式 （39）の相互平均コンプライアンス $c\left(t_{n+1}\right)$ は外力 $\mathbf{a}_{2}$ と, 計算ステップ $n, n-1$ の変位 $\chi_{n}, \chi_{n-1}$ が含まれている. 外 力 $\mathbf{a}_{2}$ は式 (34) に示したように内力で表すことができ, 周波数領域の場合と同様に, 内力を構造系, 音響系, 連 成の成分に分離するという視点に立ち, $\mathbf{a}_{2}$ を構造系, 音響系, 連成の成分に分離する. また変位 $\chi_{n}, \chi_{n-1}$ も構造系, 音響系，連成の成分に分離し，最終的に $c\left(t_{n+1}\right)$ を構造系，音響系，連成の成分に分離する. 
まず外力 $\mathbf{a}_{2}$ を分離することを考える. 外力 $\mathbf{a}_{2}$ は式（34）に示したように内力とのつり合いで表されており，外 力は次式のように構造系の内力の成分 $\mathbf{a}_{2, \mathrm{~S}}$, 音響系の内力の成分 $\mathbf{a}_{2, \mathrm{~A}}$, 連成の影響の成分 $\mathbf{a}_{2, \mathrm{Asa}}$ に分離できる. 以 下では簡単のため $\mathbf{a}_{2, \mathrm{~S}}$ を構造系の内力と呼び, $\mathbf{a}_{2, \mathrm{~A}}, \mathbf{a}_{2, \mathrm{Asa}}$ も同様に呼ぶ.

$$
\begin{aligned}
\mathbf{a}_{2} & =\mathbf{A}_{1} \chi_{n+1}-\mathbf{A}_{3} \chi_{n}-\mathbf{A}_{4} \chi_{n-1} \\
& =\mathbf{a}_{2, \mathrm{~S}}+\mathbf{a}_{2, \mathrm{~A}}+\mathbf{a}_{2, \mathrm{Asa}}
\end{aligned}
$$

ここで構造系の内力 $\mathbf{a}_{2, \mathrm{~S}}$ は次式で表され，

$$
\begin{aligned}
\mathbf{a}_{2, \mathrm{~S}} & \equiv \mathbf{A}_{1, \mathrm{~S}} \boldsymbol{\chi}_{n+1}-\mathbf{A}_{3, \mathrm{~s}} \boldsymbol{\chi}_{n}-\mathbf{A}_{4, \mathrm{~s}} \boldsymbol{\chi}_{n-1} \\
\mathbf{A}_{1, \mathrm{~S}} & =\left(\frac{1}{\Delta t^{2}}\left[\begin{array}{cc}
\mathbf{M}_{\mathrm{S}} & \mathbf{0} \\
\mathbf{0} & \mathbf{0}
\end{array}\right]+\frac{1}{2 \Delta t}\left[\begin{array}{cc}
\mathbf{D}_{\mathrm{s}} & \mathbf{0} \\
\mathbf{0} & \mathbf{0}
\end{array}\right]+\frac{1}{3}\left[\begin{array}{cc}
\mathbf{K}_{\mathrm{S}} & \mathbf{0} \\
\mathbf{0} & \mathbf{0}
\end{array}\right]\right) \\
\mathbf{A}_{3, \mathrm{~S}} & =\left(\frac{2}{\Delta t^{2}}\left[\begin{array}{cc}
\mathbf{M}_{\mathrm{S}} & \mathbf{0} \\
\mathbf{0} & \mathbf{0}
\end{array}\right]-\frac{1}{3}\left[\begin{array}{cr}
\mathbf{K}_{\mathrm{S}} & \mathbf{0} \\
\mathbf{0} & \mathbf{0}
\end{array}\right]\right) \\
\mathbf{A}_{4, \mathrm{~S}} & =\left(-\frac{1}{\Delta t^{2}}\left[\begin{array}{cc}
\mathbf{M}_{\mathrm{S}} & \mathbf{0} \\
\mathbf{0} & \mathbf{0}
\end{array}\right]+\frac{1}{2 \Delta t}\left[\begin{array}{cc}
\mathbf{D}_{\mathrm{S}} & \mathbf{0} \\
\mathbf{0} & \mathbf{0}
\end{array}\right]-\frac{1}{3}\left[\begin{array}{cc}
\mathbf{K}_{\mathrm{S}} & \mathbf{0} \\
\mathbf{0} & \mathbf{0}
\end{array}\right]\right)
\end{aligned}
$$

音響系の内力 $\mathbf{a}_{2, \mathrm{~A}}$ は

$$
\begin{aligned}
\mathbf{a}_{2, \mathrm{~A}} & \equiv \mathbf{A}_{1, \mathrm{~A}} \boldsymbol{\chi}_{n+1}-\mathbf{A}_{3, \mathrm{~A}} \boldsymbol{\chi}_{n}-\mathbf{A}_{4, \mathrm{~A}} \boldsymbol{\chi}_{n-1} \\
\mathbf{A}_{1, \mathrm{~A}} & =\left(\frac{1}{\Delta t^{2}}\left[\begin{array}{cc}
\mathbf{0} & \mathbf{0} \\
\mathbf{0} & \mathbf{M}_{\mathrm{A}}
\end{array}\right]+\frac{1}{2 \Delta t}\left[\begin{array}{cc}
\mathbf{0} & \mathbf{0} \\
\mathbf{0} & \mathbf{D}_{\mathrm{A}}
\end{array}\right]+\frac{1}{3}\left[\begin{array}{cc}
\mathbf{0} & \mathbf{0} \\
\mathbf{0} & \mathbf{K}_{\mathrm{A}}
\end{array}\right]\right) \\
\mathbf{A}_{3, \mathrm{~A}} & =\left(\frac{2}{\Delta t^{2}}\left[\begin{array}{cc}
\mathbf{0} & \mathbf{0} \\
\mathbf{0} & \mathbf{M}_{\mathrm{A}}
\end{array}\right]-\frac{1}{3}\left[\begin{array}{cc}
\mathbf{0} & \mathbf{0} \\
\mathbf{0} & \mathbf{K}_{\mathrm{A}}
\end{array}\right]\right) \\
\mathbf{A}_{4, \mathrm{~A}} & =\left(-\frac{1}{\Delta t^{2}}\left[\begin{array}{cc}
\mathbf{0} & \mathbf{0} \\
\mathbf{0} & \mathbf{M}_{\mathrm{A}}
\end{array}\right]+\frac{1}{2 \Delta t}\left[\begin{array}{cc}
\mathbf{0} & \mathbf{0} \\
\mathbf{0} & \mathbf{D}_{\mathrm{A}}
\end{array}\right]-\frac{1}{3}\left[\begin{array}{cc}
\mathbf{0} & \mathbf{0} \\
\mathbf{0} & \mathbf{K}_{\mathrm{A}}
\end{array}\right]\right)
\end{aligned}
$$

連成の影響 $\mathbf{a}_{2, \mathrm{Asa}}$ は次式で表される.

$$
\begin{aligned}
\mathbf{a}_{2, \mathrm{Asa}} & \equiv \mathbf{A}_{1, \mathrm{Asa}} \boldsymbol{\chi}_{n+1}-\mathbf{A}_{3, \mathrm{Asa}} \boldsymbol{\chi}_{n}-\mathbf{A}_{4, \mathrm{Asa}} \boldsymbol{\chi}_{n-1} \\
\mathbf{A}_{1, \mathrm{Asa}} & =\left(\frac{1}{\Delta t^{2}}\left[\begin{array}{cc}
\mathbf{0} & \mathbf{0} \\
-\mathbf{A}_{\mathrm{SA}}^{\mathrm{T}} & \mathbf{0}
\end{array}\right]+\frac{1}{3}\left[\begin{array}{cc}
\mathbf{0} & \mathbf{A}_{\mathrm{SA}} \\
\mathbf{0} & \mathbf{0}
\end{array}\right]\right) \\
\mathbf{A}_{3, \mathrm{Asa}} & =\left(\frac{2}{\Delta t^{2}}\left[\begin{array}{cc}
\mathbf{0} & \mathbf{0} \\
-\mathbf{A}_{\mathrm{SA}}^{\mathrm{T}} & \mathbf{0}
\end{array}\right]-\frac{1}{3}\left[\begin{array}{cc}
\mathbf{0} & \mathbf{A}_{\mathrm{SA}} \\
\mathbf{0} & \mathbf{0}
\end{array}\right]\right) \\
\mathbf{A}_{4, \mathrm{Asa}} & =\left(-\frac{1}{\Delta t^{2}}\left[\begin{array}{cc}
\mathbf{0} & \mathbf{0} \\
-\mathbf{A}_{\mathrm{SA}}^{\mathrm{T}} & \mathbf{0}
\end{array}\right]-\frac{1}{3}\left[\begin{array}{cc}
\mathbf{0} & \mathbf{A}_{\mathrm{SA}} \\
\mathbf{0} & \mathbf{0}
\end{array}\right]\right)
\end{aligned}
$$

次に変位 $\chi_{n}, \chi_{n-1}$ を構造系, 音響系, 連成の成分に分離することを考える. 初期変位 $\chi_{0}=0$, 初期速度 $\dot{\chi}_{0}=0$ の状 態から計算を始めたと考えると, 計算ステップ 0, およびー 1 の変位は $\chi_{0}=0, \chi_{-1}=0$ となり, 計算ステップ 1 の変 位 $\chi_{1}$ は，式（35）から次式のように外力 $\mathbf{a}_{2}$ のみで求まる.

$$
\chi_{1}=\mathbf{A}_{1}^{-1} \mathbf{a}_{2}
$$


ここで $\mathbf{a}_{2}$ を構造系，音響系，連成の成分に分離した式（40）を式（47）へ代入すると，計算ステップ1の変位 $\chi_{1}$ は次式のように構造系の成分 $\chi_{1, \mathrm{~S}}$, 音響系の成分 $\chi_{1, \mathrm{~A}}$, 連成の成分 $\chi_{1, \mathrm{Asa}}$ に分離できる.

$$
\begin{aligned}
& \chi_{1}=\chi_{1, \mathrm{~S}}+\chi_{1, \mathrm{~A}}+\chi_{1, \mathrm{Asa}} \\
& \chi_{1, \mathrm{~S}} \equiv \mathbf{A}_{1}^{-1} \mathbf{a}_{2, \mathrm{~S}} \\
& \chi_{1, \mathrm{~A}} \equiv \mathbf{A}_{1}^{-1} \mathbf{a}_{2, \mathrm{~A}} \\
& \chi_{1, \mathrm{Asa}} \equiv \mathbf{A}_{1}^{-1} \mathbf{a}_{2, \mathrm{Asa}}
\end{aligned}
$$

そして式（48）から（51）を次の計算ステップの変位計算に利用し，またその結果を次の計算ステップに順次利 用することで, 式 (35）で表される变位 $\chi_{n+1}$ を次式のように構造系の成分 $\chi_{n+1, \mathrm{~S}}$, 音響系の成分 $\chi_{n+1, \mathrm{~A}}$, 連成の成分 $\chi_{n+1, \text { Asa }}$ に分離できる.

$$
\begin{aligned}
\chi_{n+1} & =\mathbf{A}_{1}^{-1}\left(\mathbf{a}_{2}+\mathbf{A}_{3} \chi_{n}+\mathbf{A}_{4} \chi_{n-1}\right) \\
& =\mathbf{A}_{1}^{-1}\left[\left(\mathbf{a}_{2, \mathrm{~S}}+\mathbf{a}_{2, \mathrm{~A}}+\mathbf{a}_{2, \mathrm{Asa}}\right)+\mathbf{A}_{3}\left(\chi_{n, \mathrm{~S}}+\chi_{n, \mathrm{~A}}+\chi_{n, \mathrm{Asa}}\right)+\mathbf{A}_{4}\left(\chi_{n-1, \mathrm{~S}}+\chi_{n-1, \mathrm{~A}}+\chi_{n-1, \mathrm{Asa}}\right)\right] \\
& =\chi_{n+1, \mathrm{~S}}+\chi_{n+1, \mathrm{~A}}+\chi_{n+1, \mathrm{Asa}}
\end{aligned}
$$

ここで $\chi_{n+1, \mathrm{~S}}, \chi_{n+1, \mathrm{~A}}, \chi_{n+1, \mathrm{Asa}}$ は次式で表され，外力 $\mathbf{a}_{2}$ を構造系の内力 $\mathbf{a}_{2, \mathrm{~S}}$, 音響系の内力 $\mathbf{a}_{2, \mathrm{~A}}$, 連成の影響 $\mathbf{a}_{2, \mathrm{Asa}}$ に 分離している. これは式（49）から式（51）で表される計算ステップ 1 の変位 $\chi_{1, \mathrm{~S}}, \chi_{1, \mathrm{~A}}, \chi_{1, \mathrm{Asa}}$ が内力 $\mathbf{a}_{2, \mathrm{~S}}, \mathbf{a}_{2, \mathrm{~A}}$, $\mathbf{a}_{2, \mathrm{Asa}}$ で表されており, 計算ステップが進んだときの変位 $\chi_{n+1, \mathrm{~S}}, \chi_{n+1, \mathrm{~A}}, \chi_{n+1, \mathrm{Asa}}$ が，それぞれ構造系の内力による成 分，音響系の内力による成分，連成の影響による成分と言う物理的な意味を保つためである.

$$
\begin{aligned}
& \boldsymbol{\chi}_{n+1, \mathrm{~S}} \equiv \mathbf{A}_{1}^{-1}\left(\mathbf{a}_{2, \mathrm{~S}}+\mathbf{A}_{3} \boldsymbol{\chi}_{n, \mathrm{~S}}+\mathbf{A}_{4} \boldsymbol{\chi}_{n-1, \mathrm{~S}}\right) \\
& \boldsymbol{\chi}_{n+1, \mathrm{~A}} \equiv \mathbf{A}_{1}^{-1}\left(\mathbf{a}_{2, \mathrm{~A}}+\mathbf{A}_{3} \boldsymbol{\chi}_{n, \mathrm{~A}}+\mathbf{A}_{4} \boldsymbol{\chi}_{n-1, \mathrm{~A}}\right) \\
& \boldsymbol{\chi}_{n+1, \mathrm{Asa}} \equiv \mathbf{A}_{1}^{-1}\left(\mathbf{a}_{2, \mathrm{Asa}}+\mathbf{A}_{3} \boldsymbol{\chi}_{n, \mathrm{Asa}}+\mathbf{A}_{4} \boldsymbol{\chi}_{n-1, \mathrm{Asa}}\right)
\end{aligned}
$$

以上は初期変位 $\chi_{0}=0$, 初期速度 $\dot{\chi}_{0}=0$ の状態から計算を始めた場合で説明したが, 初期変位 $\chi_{0}$, 初期速度 $\dot{\chi}_{0}$ が非 零の場合であっても, 仮想的に $t<0 \quad(n<0)$ で $\chi_{n}=0, \dot{\chi}_{n}=0$ を満たす状態から計算を始めたと考えれば, 任意の $n$ に対して上述の分離式が成立する.

そして式 (40) と式（52）を式（39）に代入することで，時間領域の相互平均コンプライアンス $c\left(t_{n+1}\right)$ を次式 のように構造系の内力による成分 $c_{\mathrm{S}}\left(t_{n+1}\right)$, 音響系の内力による成分 $c_{\mathrm{A}}\left(t_{n+1}\right)$, 連成の影響による成分 $c_{\mathrm{Asa}}\left(t_{n+1}\right)$ に分 離でき，それぞれ構造系，音響系，連成の時間領域の相互平均コンプライアンスと呼ぶ.

$$
\begin{aligned}
c\left(t_{n+1}\right) & =\chi_{i}\left(t_{n+1}\right) \\
& =\mathbf{y}^{\mathrm{T}}\left[\mathbf{a}_{2}+\mathbf{A}_{3} \chi_{n}+\mathbf{A}_{4} \chi_{n-1}\right] \\
& =\mathbf{y}^{\mathrm{T}}\left[\left(\mathbf{a}_{2, \mathrm{~S}}+\mathbf{a}_{2, \mathrm{~A}}+\mathbf{a}_{2, \mathrm{Asa}}\right)+\mathbf{A}_{3}\left(\boldsymbol{\chi}_{n, \mathrm{~S}}+\boldsymbol{\chi}_{n, \mathrm{~A}}+\boldsymbol{\chi}_{n, \mathrm{Asa}}\right)+\mathbf{A}_{4}\left(\chi_{n-1, \mathrm{~S}}+\boldsymbol{\chi}_{n-1, \mathrm{~A}}+\boldsymbol{\chi}_{n-1, \mathrm{Asa}}\right)\right] \\
& =c_{\mathrm{S}}\left(t_{n+1}\right)+c_{\mathrm{A}}\left(t_{n+1}\right)+c_{\mathrm{Asa}}\left(t_{n+1}\right)
\end{aligned}
$$

ここで

$$
c_{\mathrm{S}}\left(t_{n+1}\right) \equiv \mathbf{y}^{\mathrm{T}}\left(\mathbf{a}_{2, \mathrm{~S}}+\mathbf{A}_{3} \boldsymbol{\chi}_{n, \mathrm{~S}}+\mathbf{A}_{4} \boldsymbol{\chi}_{n-1, \mathrm{~S}}\right)
$$




$$
\begin{aligned}
& c_{\mathrm{A}}\left(t_{n+1}\right) \equiv \mathbf{y}^{\mathrm{T}}\left(\mathbf{a}_{2, \mathrm{~A}}+\mathbf{A}_{3} \boldsymbol{\chi}_{n, \mathrm{~A}}+\mathbf{A}_{4} \boldsymbol{\chi}_{n-1, \mathrm{~A}}\right) \\
& c_{\mathrm{Asa}}\left(t_{n+1}\right) \equiv \mathbf{y}^{\mathrm{T}}\left(\mathbf{a}_{2, \mathrm{Asa}}+\mathbf{A}_{3} \boldsymbol{\chi}_{n, \mathrm{Asa}}+\mathbf{A}_{4} \boldsymbol{\chi}_{n-1, \mathrm{Asa}}\right)
\end{aligned}
$$

式（56）が示すように, 構造系, 音響系, 連成の時間領域の相互平均コンプライアンス $c_{\mathrm{S}}\left(t_{n+1}\right), c_{\mathrm{A}}\left(t_{n+1}\right), c_{\mathrm{Asa}}\left(t_{n+1}\right)$ の和は評価点の変位 $\chi_{i}\left(t_{n+1}\right)$ と等しく, 寄与としての性質を有することがわかる. また周波数領域の場合と同様に, 構造系の内力 $\mathbf{a}_{2, \mathrm{~S}}$ を各部品の内力に分離し, 変位 $\chi_{n+1}$ も式（47）から式（55）の手順で各部品の内力による成分に 分離することで, 構造系の相互平均コンプライアンスを部品毎の寄与に分離することも可能である. 次節では式

（56）から式（59）で表される時間領域の相互平均コンプライアンスが感度としての性質を有することを理論的 に示す.

\section{$3 \cdot 4$ 時間領域の相互平均コンプライアンスと感度の関係}

本節では時間領域の感度 $\partial \chi_{n+1} / \partial \alpha$ 導出し, 前節で定義した時間領域の相互平均コンプライアンスと感度の関係 を明らかにする．まず設計変数 $\alpha$ と特性行列の関係を任意とし， $\partial \mathbf{K} / \partial \alpha, \partial \mathbf{D} / \partial \alpha, \partial \mathbf{M} / \partial \alpha$ を含んだ時間領域の感度 を導出する. そして設計変数 $\alpha$ と特性行列の関係を, 周波数領域の相互平均コンプライアンスと感度の関係を示 したのと同様に， $\mathbf{K}^{\prime}=(1+\alpha) \mathbf{K}$ とおき，時間領域の相互平均コンプライアンスと時間領域の感度の関係を示す。

運動方程式を時間方向に離散化した式（32）を設計変数 $\alpha$ で偏微分すると次式を得る.

$$
\begin{aligned}
& \frac{\partial \mathbf{A}_{1}}{\partial \alpha} \boldsymbol{\chi}_{n+1}+\mathbf{A}_{1} \frac{\partial \boldsymbol{\chi}_{n+1}}{\partial \alpha}=\frac{\partial \mathbf{A}_{3}}{\partial \alpha} \boldsymbol{\chi}_{n}+\mathbf{A}_{3} \frac{\partial \boldsymbol{\chi}_{n}}{\partial \alpha}+\frac{\partial \mathbf{A}_{4}}{\partial \alpha} \boldsymbol{\chi}_{n-1}+\mathbf{A}_{4} \frac{\partial \boldsymbol{\chi}_{n-1}}{\partial \alpha} \\
& \frac{\partial \mathbf{A}_{1}}{\partial \alpha} \equiv\left(\frac{1}{\Delta t^{2}} \frac{\partial \mathbf{M}}{\partial \alpha}+\frac{1}{2 \Delta t} \frac{\partial \mathbf{D}}{\partial \alpha}+\frac{1}{3} \frac{\partial \mathbf{K}}{\partial \alpha}\right), \frac{\partial \mathbf{A}_{3}}{\partial \alpha} \equiv\left(\frac{2}{\Delta t^{2}} \frac{\partial \mathbf{M}}{\partial \alpha}-\frac{1}{3} \frac{\partial \mathbf{K}}{\partial \alpha}\right), \quad \frac{\partial \mathbf{A}_{4}}{\partial \alpha} \equiv\left(-\frac{1}{\Delta t^{2}} \frac{\partial \mathbf{M}}{\partial \alpha}+\frac{1}{2 \Delta t} \frac{\partial \mathbf{D}}{\partial \alpha}-\frac{1}{3} \frac{\partial \mathbf{K}}{\partial \alpha}\right)
\end{aligned}
$$

ここで外力を表す $\mathbf{a}_{2}$ は設計変数 $\alpha$ の変化に対して不変であるとした $\left(\partial \mathbf{a}_{2} / \partial \alpha=0\right)$. 本式を整理すると次式を得る.

$$
\frac{\partial \boldsymbol{\chi}_{n+1}}{\partial \alpha}=\mathbf{A}_{1}^{-1}\left(\mathbf{a}_{\alpha}+\mathbf{A}_{3} \frac{\partial \boldsymbol{\chi}_{n}}{\partial \alpha}+\mathbf{A}_{4} \frac{\partial \boldsymbol{\chi}_{n-1}}{\partial \alpha}\right)
$$

ここで

$$
\mathbf{a}_{\alpha} \equiv-\left(\frac{\partial \mathbf{A}_{1}}{\partial \alpha} \chi_{n+1}-\frac{\partial \mathbf{A}_{3}}{\partial \alpha} \boldsymbol{\chi}_{n}-\frac{\partial \mathbf{A}_{4}}{\partial \alpha} \boldsymbol{\chi}_{n-1}\right)
$$

本式と式（34）の外力 $\mathbf{a}_{2}$ と内力を表す関係式 $\mathbf{a}_{2}=\mathbf{A}_{1} \chi_{n+1}-\mathbf{A}_{3} \chi_{n}-\mathbf{A}_{4} \chi_{n-1}$ の比較から， $\mathbf{a}_{\alpha}$ は設計変数 $\alpha$ の変化によって特 性行列が変化したときの内力の変化率 $\times-1$ を表すと考えられる. $\mathbf{a}_{\alpha}$ は式 (40) と同様に構造系に起因する内力 の変化率 $\mathbf{a}_{\alpha, \mathrm{S}}$, 音響系に起因する内力の変化率 $\mathbf{a}_{\alpha, \mathrm{A}}$, 連成に起因する変化率 $\mathbf{a}_{\alpha, \mathrm{Asa}}$ に分離できる.

$$
\begin{aligned}
& \mathbf{a}_{\alpha}=\mathbf{a}_{\alpha, \mathrm{S}}+\mathbf{a}_{\alpha, \mathrm{A}}+\mathbf{a}_{\alpha, \mathrm{Asa}} \\
& \mathbf{a}_{\alpha, \mathrm{S}} \equiv-\left(\frac{\partial \mathbf{A}_{1, \mathrm{~S}}}{\partial \alpha} \boldsymbol{\chi}_{n+1}-\frac{\partial \mathbf{A}_{3, \mathrm{~S}}}{\partial \alpha} \boldsymbol{\chi}_{n}-\frac{\partial \mathbf{A}_{4, \mathrm{~S}}}{\partial \alpha} \boldsymbol{\chi}_{n-1}\right) \\
& \mathbf{a}_{\alpha, \mathrm{A}} \equiv-\left(\frac{\partial \mathbf{A}_{1, \mathrm{~A}}}{\partial \alpha} \boldsymbol{\chi}_{n+1}-\frac{\partial \mathbf{A}_{3, \mathrm{~A}}}{\partial \alpha} \boldsymbol{\chi}_{n}-\frac{\partial \mathbf{A}_{4, \mathrm{~A}}}{\partial \alpha} \boldsymbol{\chi}_{n-1}\right) \\
& \mathbf{a}_{\alpha, \mathrm{Asa}} \equiv-\left(\frac{\partial \mathbf{A}_{1, \mathrm{Asa}}}{\partial \alpha} \boldsymbol{\chi}_{n+1}-\frac{\partial \mathbf{A}_{3, \mathrm{Asa}}}{\partial \alpha} \boldsymbol{\chi}_{n}-\frac{\partial \mathbf{A}_{4, \mathrm{Asa}}}{\partial \alpha} \boldsymbol{\chi}_{n-1}\right)
\end{aligned}
$$

本式の $\mathbf{A}_{i, \mathrm{~S}}, \mathbf{A}_{i, \mathrm{~A}}, \mathbf{A}_{i, \mathrm{Asa}}$ は式 (42)，（44），(46）で定義された行列である. 
ここで変位 $\boldsymbol{\chi}_{n+1}$ を求める式（35） と感度 $\partial \chi_{n+1} / \partial \alpha$ を求める式（61）を比較すると, 外力 $\mathbf{a}_{2}$ を内力の変化率 $\mathbf{a}_{\alpha}$ に 置き換えることで, 変位 $\chi_{n+1}$ を求める式と同一の式で感度 $\partial \chi_{n+1} / \partial \alpha$ を求められることがわかる. よって式 (47) か ら式（55）で説明した変位 $\chi_{n+1}$ を構造系の内力による成分 $\chi_{n+1, S}$, 音響系の内力による成分 $\chi_{n+1, \mathrm{~A}}$, 連成の影響によ る成分 $\chi_{n+1, \mathrm{Asa}}$ に分離する際と同じ議論が成立し, 感度 $\partial \chi_{n+1} / \partial \alpha$ を次式のように構造系の成分 $\left(\partial \chi_{n+1} / \partial \alpha\right)_{\mathrm{S}}$, 音響系の 成分 $\left(\partial \chi_{n+1} / \partial \alpha\right)_{\mathrm{A}}$, 連成の成分 $\left(\partial \chi_{n+1} / \partial \alpha\right)_{\mathrm{Asa}}$ に分離できる.

$$
\begin{aligned}
& \frac{\partial \boldsymbol{\chi}_{n+1}}{\partial \alpha}=\left(\frac{\partial \boldsymbol{\chi}_{n+1}}{\partial \alpha}\right)_{\mathrm{S}}+\left(\frac{\partial \boldsymbol{\chi}_{n+1}}{\partial \alpha}\right)_{\mathrm{A}}+\left(\frac{\partial \boldsymbol{\chi}_{n+1}}{\partial \alpha}\right)_{\mathrm{Asa}} \\
& \left(\frac{\partial \boldsymbol{\chi}_{n+1}}{\partial \alpha}\right)_{\mathrm{S}} \equiv \mathbf{A}_{1}^{-1}\left(\mathbf{a}_{\alpha, \mathrm{S}}+\mathbf{A}_{3}\left(\frac{\partial \boldsymbol{\chi}_{n}}{\partial \alpha}\right)_{\mathrm{S}}+\mathbf{A}_{4}\left(\frac{\partial \boldsymbol{\chi}_{n-1}}{\partial \alpha}\right)_{\mathrm{S}}\right) \\
& \left(\frac{\partial \boldsymbol{\chi}_{n+1}}{\partial \alpha}\right)_{\mathrm{A}} \equiv \mathbf{A}_{1}^{-1}\left(\mathbf{a}_{\alpha, \mathrm{A}}+\mathbf{A}_{3}\left(\frac{\partial \boldsymbol{\chi}_{n}}{\partial \alpha}\right)_{\mathrm{A}}+\mathbf{A}_{4}\left(\frac{\partial \boldsymbol{\chi}_{n-1}}{\partial \alpha}\right)_{\mathrm{A}}\right) \\
& \left(\frac{\partial \boldsymbol{\chi}_{n+1}}{\partial \alpha}\right)_{\mathrm{Asa}} \equiv \mathbf{A}_{1}^{-1}\left(\mathbf{a}_{\alpha, \mathrm{Asa}}+\mathbf{A}_{3}\left(\frac{\partial \boldsymbol{\chi}_{n}}{\partial \alpha}\right)_{\mathrm{Asa}}+\mathbf{A}_{4}\left(\frac{\partial \boldsymbol{\chi}_{n-1}}{\partial \alpha}\right)_{\mathrm{Asa}}\right)
\end{aligned}
$$

以上は設計変数 $\alpha$ と特性行列の関係を任意とした場合の時間領域の感度である.

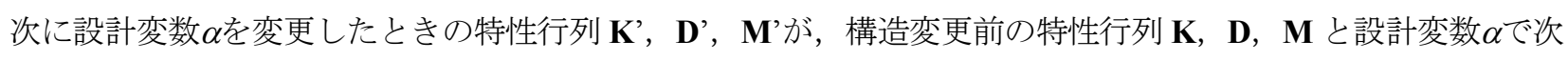
式のように表せると仮定した場合の感度 $\partial \chi_{n+1} / \partial \alpha を$ 考える.

$$
\mathbf{K}^{\prime}=(1+\alpha) \mathbf{K}, \quad \mathbf{D}^{\prime}=(1+\alpha) \mathbf{D}, \quad \mathbf{M}^{\prime}=(1+\alpha) \mathbf{M}
$$

このとき式（60）の $\partial \mathbf{A}_{1} / \partial \alpha, \partial \mathbf{A}_{3} / \partial \alpha, \partial \mathbf{A}_{4} / \partial \alpha$ は次式で表される.

$$
\frac{\partial \mathbf{A}_{1}}{\partial \alpha}=\mathbf{A}_{1}, \quad \frac{\partial \mathbf{A}_{3}}{\partial \alpha}=\mathbf{A}_{3}, \quad \frac{\partial \mathbf{A}_{4}}{\partial \alpha}=\mathbf{A}_{4}
$$

式（72）を式（62）に代入し整理すると， $\mathbf{a}_{\alpha}$ は次式のように外力 $\mathbf{a}_{2} \times-1$ で表される.

$$
\begin{aligned}
\mathbf{a}_{\alpha} & =-\left(\mathbf{A}_{1} \chi_{n+1}-\mathbf{A}_{3} \chi_{n}-\mathbf{A}_{4} \chi_{n-1}\right) \\
& =-\mathbf{a}_{2}
\end{aligned}
$$

すなわち式（71）のように設計変数 $\alpha$ の変化に対して特性行列が $\alpha$ 割変化すると仮定したときの内力の変化率 $\mathbf{a}_{\alpha}$ は, 式（34）で表される外力 $\mathbf{a}_{2}$ にー1 を乗じたものと等しくなる. 式（73）を感度 $\partial x_{n+1} / \partial \alpha$ を求める式（61） 代入すると次式を得る.

$$
\frac{\partial \boldsymbol{\chi}_{n+1}}{\partial \alpha}=\mathbf{A}_{1}^{-1}\left(-1 \times \mathbf{a}_{2}+\mathbf{A}_{3} \frac{\partial \boldsymbol{\chi}_{n}}{\partial \alpha}+\mathbf{A}_{4} \frac{\partial \boldsymbol{\chi}_{n-1}}{\partial \alpha}\right)
$$

本式と変位 $\chi_{n+1}$ を求める式（35）を比較する. 式（35）を再記する.

$$
\chi_{n+1}=\mathbf{A}_{1}^{-1}\left(\mathbf{a}_{2}+\mathbf{A}_{3} \chi_{n}+\mathbf{A}_{4} \chi_{n-1}\right)
$$

式（74）と式（35）の右辺を比較すると, 式（74）の感度 $\partial \chi_{n+1} / \partial \alpha て ゙ は$ 外力 $\mathbf{a}_{2}$ が一方向（負の方向）に作用して いるが，式（74）と式（35）の $\mathbf{a}_{2}$ 以外の項は同符号で，かつ $\partial \chi / \partial \alpha ， \chi$ の係数行列が等しいことがわかる. そして 初期変位 $\chi_{0}=0$, 初期速度 $\dot{\chi}_{0}=0$ の状態から計算を始めたと考えると, 計算ステップ $n=0$, および $n=-1$ の変位と 感度はそれぞれ $\chi_{0}=0, \chi_{-1}=0, \quad \partial \chi_{0} / \partial \alpha=0, \partial \chi_{-1} / \partial \alpha=0$ となり, 式（35）（74）の結果として次式が成立する.

$$
\frac{\partial \chi_{1}}{\partial \alpha}=-\chi_{1}
$$


初期変位 $\chi_{0}$, 初期速度 $\dot{\chi}_{0}$ が非零の場合であっても, 仮想的に $t<0 \quad(n<0)$ で $\chi_{n}=0, \quad \dot{\chi}_{n}=0$ を満たす状態から計算 を始めたと考えれば，任意の $n$ に対して次式が成立する.

$$
\frac{\partial \boldsymbol{\chi}_{n+1}}{\partial \alpha}=-\boldsymbol{\chi}_{n+1}
$$

すなわち設計変数 $\alpha$ 変化に対して特性行列が $\alpha$ 割変化すると仮定したときの感度 $\partial \chi_{n+1} / \partial \alpha$ は, 変位 $\chi_{n+1}$ に一 1 を乗 じたものと等しい.

感度 $\partial \chi_{n+1} / \partial \alpha$ は系全体の自由度を含んだベクトルであり, 評価点 $i$ の時刻 $n+1$ の感度 $\partial \chi_{i}\left(t_{n+1}\right) / \partial \alpha$ は, 随伴荷重 $\mathbf{g}_{i}$ の転置を式（74）の左から乗じることで次式のように求まる.

$$
\begin{aligned}
\frac{\partial \chi_{i}\left(t_{n+1}\right)}{\partial \alpha} & =\mathbf{g}_{i}^{\mathrm{T}} \frac{\partial \boldsymbol{\chi}_{n+1}}{\partial \alpha}=-\mathbf{y}^{\mathrm{T}}\left(\mathbf{a}_{2}+\mathbf{A}_{3} \boldsymbol{\chi}_{n}+\mathbf{A}_{4} \boldsymbol{\chi}_{n-1}\right) \\
& =-\chi_{i}\left(t_{n+1}\right) \\
& =-c\left(t_{n+1}\right)
\end{aligned}
$$

本式の変換では, 式（76）から得られる関係式 $\partial \chi_{n} / \partial \alpha=-\chi_{n}, \partial \chi_{n-1} / \partial \alpha=-\chi_{n-1}$ を利用した. 式（77）は, 設計変数 $\alpha$ の変化に対して特性行列が $\alpha$ 割変化すると仮定したときの感度 $\partial \chi_{i}\left(t_{n+1}\right) / \partial \alpha か ゙$, 式（39）で表される時間領域の相互 平均コンプライアンス $c\left(t_{n+1}\right) \times-1$ と等しいことを示している.

次に感度の構造系成分と相互平均コンプライアンスの構造系成分の関係を考察する. 設計変数 $\alpha$ の変化に対し て特性行列が $\alpha$ 割変化すると仮定したとき, 式（64）で表される構造系に起因する内力の変化率 $\mathbf{a}_{\alpha, S}$ は, 式（41） で表される構造系の内力 $\mathbf{a}_{2, \mathrm{~S}} \times-1$ と等しくなる.

$$
\begin{aligned}
\mathbf{a}_{\alpha, \mathrm{S}} & =-\left(\frac{\partial \mathbf{A}_{1, \mathrm{~S}}}{\partial \alpha} \boldsymbol{\chi}_{n+1}-\frac{\partial \mathbf{A}_{3, \mathrm{~s}}}{\partial \alpha} \boldsymbol{\chi}_{n}-\frac{\partial \mathbf{A}_{4, \mathrm{~S}}}{\partial \alpha} \boldsymbol{\chi}_{n-1}\right) \\
& =-\left(\mathbf{A}_{1, \mathrm{~s}} \boldsymbol{\chi}_{n+1}-\mathbf{A}_{3, \mathrm{~s}} \boldsymbol{\chi}_{n}-\mathbf{A}_{4, \mathrm{~s}} \boldsymbol{\chi}_{n-1}\right)=-\mathbf{a}_{2, \mathrm{~S}}
\end{aligned}
$$

本式の関係式 $\mathbf{a}_{\alpha, S}=-\mathbf{a}_{2, \mathrm{~S}}$ から, 式（76）の感度 $\partial \chi_{n+1} / \partial \alpha$ と変位 $\chi_{n+1}$ の関係を導出した議論が構造系成分についても 成立し， $\left(\partial \chi_{n+1} / \partial \alpha\right)_{\mathrm{S}}=-\chi_{n+1, \mathrm{~S}}$ が成立する. よって式（68）の感度の構造系成分 $\left(\partial \chi_{n+1} / \partial \alpha\right)_{\mathrm{S}}$ は次式のように構造系の 内力 $\mathbf{a}_{2, \mathrm{~S}}$ と変位の構造系成分 $\chi_{n, \mathrm{~S}}, \chi_{n-1, \mathrm{~S}}$ で表される.

$$
\begin{aligned}
\left(\frac{\partial \boldsymbol{\chi}_{n+1}}{\partial \alpha}\right)_{\mathrm{S}} & =\mathbf{A}_{1}^{-1}\left(-\mathbf{a}_{\alpha, \mathrm{S}}+\mathbf{A}_{3}\left(\frac{\partial \boldsymbol{\chi}_{n}}{\partial \alpha}\right)_{\mathrm{S}}+\mathbf{A}_{4}\left(\frac{\partial \boldsymbol{\chi}_{n-1}}{\partial \alpha}\right)_{\mathrm{S}}\right) \\
& =-\mathbf{A}_{1}^{-1}\left(\mathbf{a}_{2, \mathrm{~S}}+\mathbf{A}_{3} \boldsymbol{\chi}_{n, \mathrm{~S}}+\mathbf{A}_{4} \boldsymbol{\chi}_{n-1, \mathrm{~S}}\right)
\end{aligned}
$$

評価点 $i$ の感度は, 式（79）の左から随伴荷重 $\mathbf{g}_{i}$ の転置を乗じることで次式のように求まり, 評価点 $i$ の感度の 構造系成分 $\left(\partial \chi_{i, n+1} / \partial \alpha\right)_{\mathrm{S}}$ と構造系の相互平均コンプライアンス $c_{\mathrm{S}}\left(t_{n+1}\right)$ の関係が導かれる.

$$
\begin{aligned}
\left(\frac{\partial \chi_{i, n+1}}{\partial \alpha}\right)_{\mathrm{S}} & =-\mathbf{g}_{i}^{\mathrm{T}} \mathbf{A}_{1}^{-1}\left(\mathbf{a}_{2, \mathrm{~S}}+\mathbf{A}_{3} \boldsymbol{\chi}_{n, \mathrm{~S}}+\mathbf{A}_{4} \boldsymbol{\chi}_{n-1, \mathrm{~S}}\right) \\
& =-\mathbf{y}^{\mathrm{T}}\left(\mathbf{a}_{2, \mathrm{~S}}+\mathbf{A}_{3} \boldsymbol{\chi}_{n, \mathrm{~S}}+\mathbf{A}_{4} \boldsymbol{\chi}_{n-1, \mathrm{~S}}\right) \\
& =-c_{\mathrm{S}}\left(t_{n+1}\right)
\end{aligned}
$$

式（80）は，感度の構造系成分が式（57）で表される時間領域の相互平均コンプライアンスの構造系成分 $c_{\mathrm{s}}\left(t_{\mathrm{n}+1}\right)$ $\times-1$ と等しいことを示している. 式（78）から式（80）の展開を，音響系の成分，連成の成分に対して行うこ とで, 音響系, 連成の時間領域の相互平均コンプライアンスが, 感度の音響系成分 $\times-1$, 連成成分 $\times-1$ となる ことを理論的に示すことができる.

3.3 節，3.4 節の結果から，式（56）から式（59）で表される時間領域の相互平均コンプライアンスが寄与と感 度の両方の性質を有することが理論的に示された. 


\section{6 自由度構造音響連成系での検証}

本章では 6 自由度構造音響連成系に周波数領域と時間領域の相互平均コンプライアンスを適用し，時間領域の 相互平均コンプライアンスの物理的な意味を説明する. そして時間領域の相互平均コンプライアンスが寄与と感 度の両方の性質を持つことを確認する. また時間領域の相互平均コンプライアンスを中心差分法で求めることで, 系の非線形性も考慮できることを示寸.

\section{$4 \cdot 1$ 時間領域の相互平均コンプライアンスの寄与としての性質の確認}

はじめに周波数領域の相互平均コンプライアンス $c(\omega)$ を逆フーリエ変換して求めた時間領域の相互平均コン プライアンスと, 中心差分法で求めた時間領域の相互平均コンプライアンス $c(t)$ が等しくなることを確認する. 図 1 に 6 自由度構造音響連成系を示す. 系の特性行列は次式で表され，外力は構造系節点 1,3 に作用しており， 音圧の評価点は音響系節点 1 とする. 構造系は $m_{1}=0.01 \mathrm{~kg}, m_{2}=m_{3}=0.1 \mathrm{~kg}, k_{1}=k_{2}=1.0 \times 10^{3} \mathrm{~N} / \mathrm{m}, k_{3}=k_{4}=1.0 \times$ $10^{4} \mathrm{~N} / \mathrm{m}$, 音響系の要素長さを $L=2.0 \mathrm{~m}$, 空気の密度を $\rho=1.21 \mathrm{~kg} / \mathrm{m}^{3}$, 音速を $c=343 \mathrm{~m} / \mathrm{s}$, 構造系と音響系が接する面 の面積を $A=0.4 \mathrm{~m}^{2}$ とした. 減衰は比例粘性減衰を仮定し $\alpha=0, \beta=1.0 \times 10^{-5}$ とし, 中心差分法の時間刻みは $\mathrm{d} t=1.0$ $\times 10^{-4} \mathrm{~s}$ とした.

$$
\begin{aligned}
& \mathbf{M}_{\mathrm{S}}=\left[\begin{array}{ccc}
m_{1} & 0 & 0 \\
0 & m_{2} & 0 \\
0 & 0 & m_{3}
\end{array}\right], \quad \mathbf{K}_{\mathrm{S}}=\left[\begin{array}{ccc}
k_{1}+k_{2} & -k_{2} & 0 \\
-k_{2} & k_{2}+k_{3} & -k_{3} \\
0 & -k_{3} & k_{3}+k_{4}
\end{array}\right], \quad \mathbf{D}_{\mathrm{S}}=\alpha \mathbf{M}_{\mathrm{S}}+\beta \mathbf{K}_{\mathrm{S}}, \\
& \mathbf{M}_{\mathrm{A}}=\left[\begin{array}{ccc}
2 m_{\mathrm{A}} & m_{\mathrm{A}} & 0 \\
m_{\mathrm{A}} & 4 m_{\mathrm{A}} & m_{\mathrm{A}} \\
0 & m_{\mathrm{A}} & 2 m_{\mathrm{A}}
\end{array}\right], \quad \mathbf{K}_{\mathrm{A}}=\left[\begin{array}{ccc}
k_{\mathrm{A}} & -k_{\mathrm{A}} & 0 \\
-k_{\mathrm{A}} & 2 k_{\mathrm{A}} & -k_{\mathrm{A}} \\
0 & -k_{\mathrm{A}} & k_{\mathrm{A}}
\end{array}\right], \quad \mathbf{D}_{\mathrm{A}}=\alpha \mathbf{M}_{\mathrm{A}}+\beta \mathbf{K}_{\mathrm{A}}, \\
& \mathbf{A}_{\mathrm{SA}}=\left[\begin{array}{ccc}
0 & 0 & 0 \\
A & 0 & 0 \\
0 & 0 & -A
\end{array}\right], \quad \mathbf{f}_{\mathrm{S}}=\left\{\begin{array}{c}
1 \\
0 \\
-1
\end{array}\right\}, \quad \mathbf{f}_{\mathrm{A}}=\left\{\begin{array}{l}
0 \\
0 \\
0
\end{array}\right\}, \quad m_{\mathrm{A}}=\frac{A L}{6 \rho c^{2}}, \quad k_{\mathrm{A}}=\frac{A}{\rho L}
\end{aligned}
$$

図 2 に評価点音圧の周波数応答 $p_{1}(\omega)$ を黒線，周波数領域の相互平均コンプライアンスから求めた $p_{1}(\omega)$ に対す る質量 $m_{3}$ の寄与 $c_{m 3}(\omega)$ を赤線で示す. 対象周波数は $0 \mathrm{~Hz}$ から $f_{\max }=5 \mathrm{kHz}$, 周波数刻み $\mathrm{d} f=0.01 \mathrm{~Hz}$ で計算した. $f_{\max }=5 \mathrm{kHz}, \mathrm{d} f=0.01 \mathrm{~Hz}$ とした理由は，離散逆フーリエ変換の変換誤差を小さくするためである. 質量 $m_{3}$ の相互平 均コンプライアンス $c_{m 3}(\omega)$ を逆フーリエ変換して求めた時間領域の相互平均コンプライアンスを図 3 に赤線で示 し, 中心差分法で求めた相互平均コンプライアンス $c_{m 3}(t)$ を図 3 に青破線で示寸. 図 3 から, それら二つがよく一 致しており, 中心差分法で求めた時間領域の相互平均コンプライアンスが妥当であることが確認できる. 周波数 領域の相互平均コンプライアンスは, 着目自由度までの伝達関数と内力の積で表されていることから，時間領域 の相互平均コンプライアンスもまた, 着目自由度までの伝達関数と内力の積を時間領域に変換したものであるこ とが確認できる.

次に式 (57) から（59）で表される時間領域の相互平均コンプライアンスの構造系成分 $c_{\mathrm{S}}(t)$, 音響系成分 $c_{\mathrm{A}}(t)$, 連成の成分 $c_{\mathrm{Asa}}(t)$ の和が音圧 $p_{1}(t)$ と等しいことを確認し, 時間領域の相互平均コンプライアンスが寄与としての 性質を持つことを確認する. 図 4 に $p_{1}(t)$ を黒線で示し， $c_{\mathrm{S}}(t)$ を赤線， $c_{\mathrm{A}}(t)$ を青破線， $c_{\mathrm{Asa}}(t)$ を緑線で表す．また相 互平均コンプライアンスの和 $c_{\mathrm{S}}(t)+c_{\mathrm{A}}(t)+c_{\mathrm{Asa}}(t)$ を赤紫の破線で示寸. 図 4 から時間領域の相互平均コンプライア ンスの和は着目応答 $p_{1}(t)$ と等しく, 時間領域の相互平均コンプライアンスが応答に対する寄与の性質を持つこと が確認できる. 


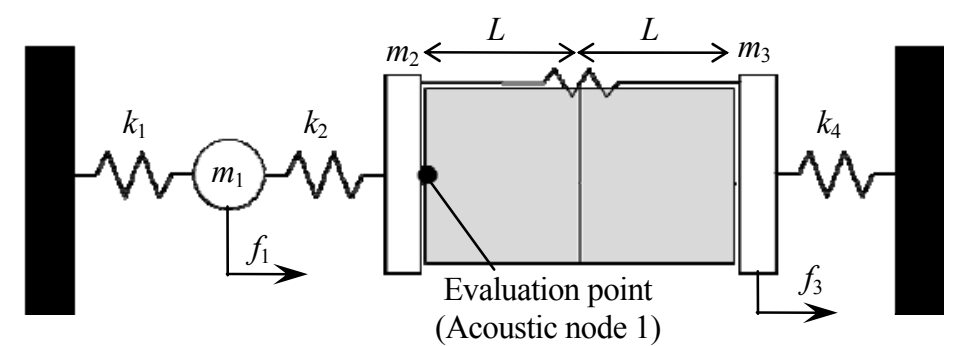

Fig. 1 Simple vibro - acoustic model.

- Frequency response $p_{1}(\omega)$

$-c_{m 3}(\omega)$; Frequency domain mutual mean compliance of $m_{3}$
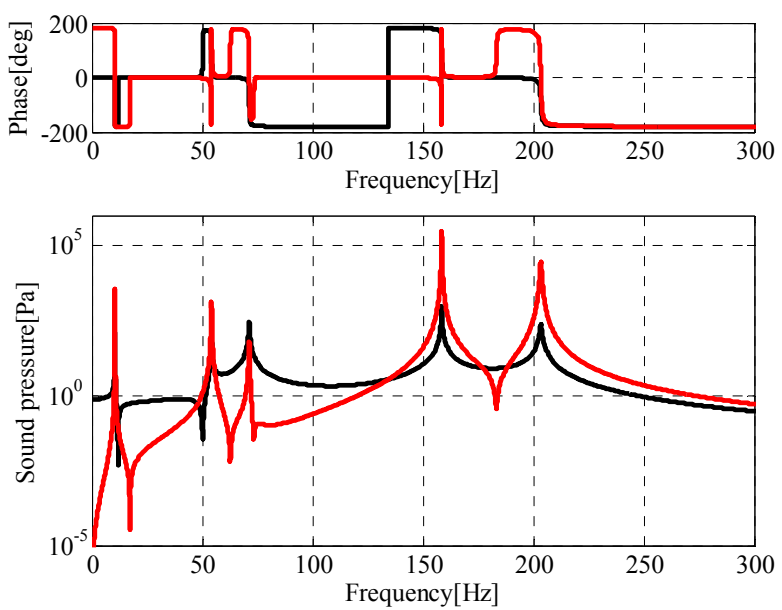

Fig. 2 Frequency response $p_{1}(\omega)$ (black line) and frequency domain mutual mean compliance $c_{m 3}(\omega)$ (red line). $c_{m 3}(\omega)$ indicates the contribution of $m_{3}$ to the frequency response $p_{1}(\omega)$.

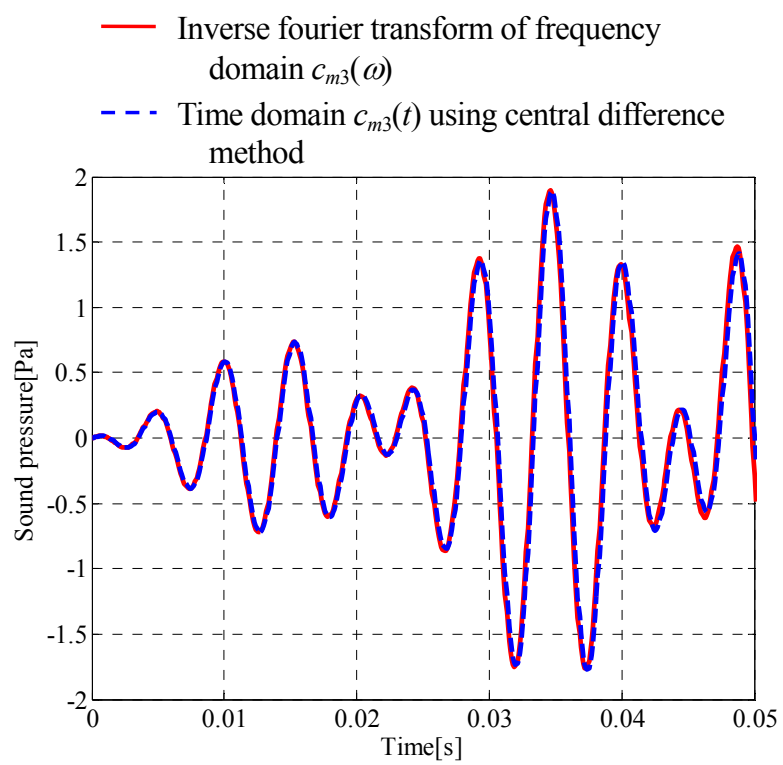

Fig. 3 Comparison between two types of time domain mutual mean compliance. One is obtained from inverse fourier transform of frequency domain $c_{m 3}(\omega)$ (red line), another is calculated by central difference method (blue dashed line). These lines overlap each other, and consequently, it indicates validity of time domain $c_{m 3}(t)$ calculated by central difference method.

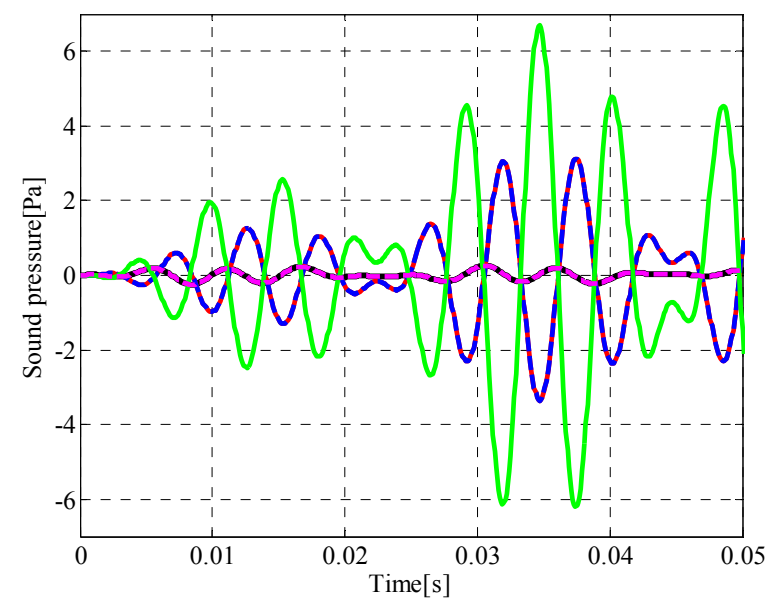

\footnotetext{
- Target sound pressure $p_{1}(t)$

$c_{\mathrm{S}}(t)$

$--c_{\mathrm{A}}(t)$

$-c_{\mathrm{Asa}}(t)$

- - - Summation of mutual mean compliance
}

Fig. 4 Comparison between time history response $p_{1}(t)$ (black line) and the summation of time domain mutual mean compliances (magenta dashed line). Red line indicates the time domain mutual mean compliance of structural system. Blue dashed line and green line indicate the acoustical component and coupling component respectively. 


\section{$4 \cdot 2$ 時間領域の相互平均コンプライアンスの感度としての性質の確認}

本節では構造変更を行った際の応答変化量を時間領域の相互平均コンプライアンスを用いて予測し，相互平均 コンプライアンスが時刻歴応答に対する感度の性質を持つことを確認する. 図 1 に示した 6 自由度系の質量 $m_{3}$ を $0.1 \mathrm{~kg}$ から $1 \%$ 増加させ $0.101 \mathrm{~kg}\left(\mathrm{~d} m_{3}=0.001 \mathrm{~kg}\right)$ に変更した。 このときの評価点音圧の時刻歴応答 $p_{1}(t)$ の応答 変化量 $\mathrm{d} p_{1}(t)$ を図 5 に黒線で示寸. 応答変化量 $\mathrm{d} p_{1}(t)$ は質量増加後の応答 $p_{1}^{\prime}(t)$ と質量増加前の応答 $p_{1}(t)$ の差分であ り, $\mathrm{d} p_{1}(t)=p_{1}^{\prime}(t)-p_{1}(t)$ から求まる. また時間領域の相互平均コンプライアンス $c(t)$ を用いて予測した応答変化量 $\overline{d p}_{1}(t)$ を図 5 に青破線で示す. 時間領域の相互平均コンプライアンスは感度 $\times-1$ と等しいことから, 質量 $m_{3}$ が $\mathrm{d} m_{3}$ 変化したときの応答変化量の予測值 $\overline{d p}_{1}(t)$ は $\overline{d p}_{1}(t)=-1 \times c_{m 3}(t) \times \mathrm{d} m_{3}$ で求まる. 図 5 に示したように質量が $1 \%$ 増加する程度の微小な構造変更では, 実際の応答の変化量 $\mathrm{d} p_{1}(t)$ と予測值 $\overline{d p} 1(t)$ はよく一致しており, 時間領域の 相互平均コンプライアンスが時刻歴応答に対する感度の性質を持つことが確認できる. 応答変化量の定量予測は 構造変更量が微小の場合にのみ可能であり, 構造変更量が大きくなるほど予測精度は低くなるが, 相互平均コン プライアンスは寄与の性質も有するため, 現状の振動現象に対する各要素の寄与と感度の両方を把握でき, 構造 変更を行う上での一つの指針を示すことが可能であると考えられる.

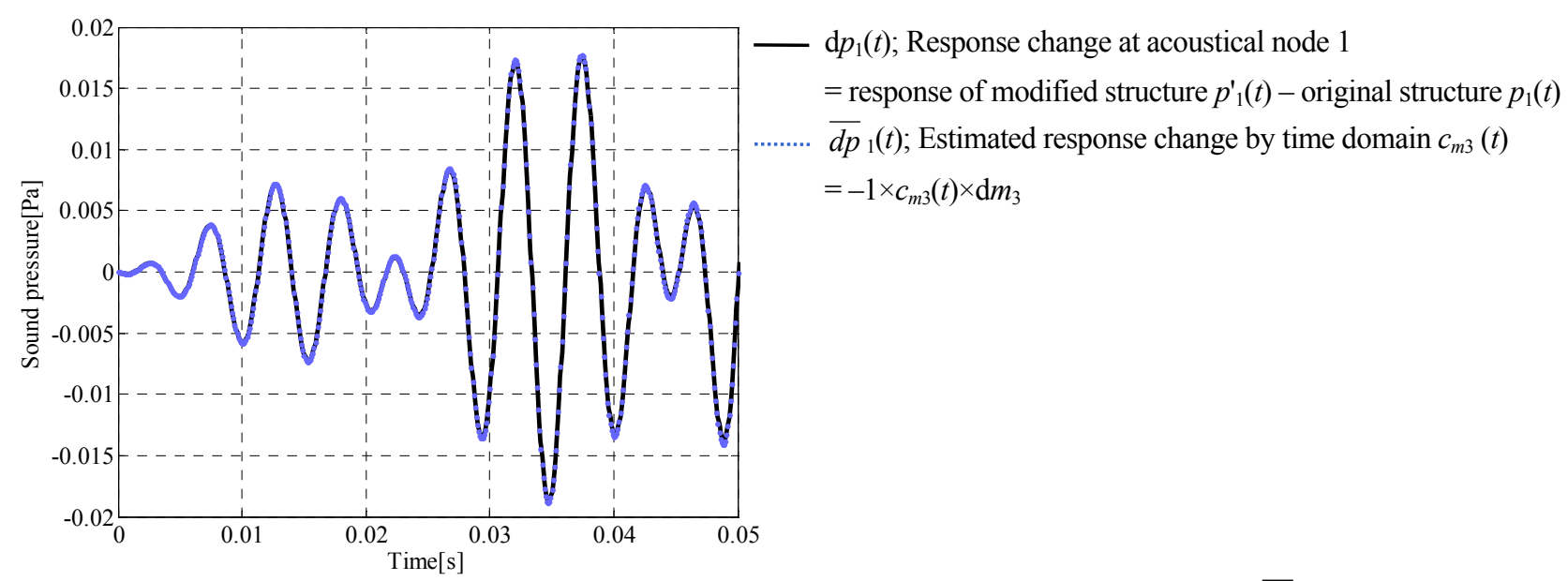

Fig. 5 Comparison between response change $\mathrm{d} p_{1}(t)$ (black line) and estimated response change $\overline{d p}_{1}(t)$ by time domain $c_{m 3}(t)$ (blue dot line). These lines overlap each other, it indicates that characteristic of time domain mutual mean compliance $c(t)$ corresponds to that of sensitivity of each component.

\section{$4 \cdot 3$ 非線形性を有する場合の検証}

本節では時間領域の相互平均コンプライアンスを中心差分法で求めることで，系の非線形性も考慮可能である ことを示す. 図 1 の 6 自由度系のばね $k_{1}$ を振幅依存をもつ非線形ばねとし, 図 6 に黒線で示すように変位 $\left|x_{1}\right|$ が $5.0 \times 10^{-3} \mathrm{~mm}$ より小さい場合はばね定数を $k_{1, \mathrm{Soft}}=1.0 \times 10^{3} \mathrm{~N} / \mathrm{m}$ とし, 変位 $\left|x_{1}\right|$ が $5.0 \times 10^{-3} \mathrm{~mm}$ 以上の場合は $k_{1, \mathrm{Hard}}=2.0$ $\times 10^{3} \mathrm{~N} / \mathrm{m}$ とする. 図 7 に $k_{1}$ を非線形ばねとしたときの音圧 $p_{1}(t)$ を赤線で示し, 前節までと同じ線形ばねとした ときの音圧 $p_{1}(t)$ を黒線で示寸. ばねの非線形性によって音圧 $p_{1}(t)$ が変化していることがわかる. 中心差分法で求 めた時間領域の相互平均コンプライアンスの精度を検証するために，非線形ばねのばね定数 $k_{1, \text { Soft }}, k_{1, \text { Hard }}$ をそれ ぞれ $5 \%$ 増加させたときの音圧 $p_{1}(t)$ の変化量を時間領域の相互平均コンプライアンス $c_{k 1}(t)$ で予測する. $k_{1, \mathrm{Soft}}, k_{1, \mathrm{Hard}}$ を $5 \%$ 増加させたときのばねの変位と力の関係を図 6 に赤破線で示寸. また図 8 に, $k_{1, \text { Soft }}, k_{1, H a r d}$ を $5 \%$ 増加させた ときの実際の応答変化量 $\mathrm{d} p_{1}(t)$ を黒線で示し, 時間領域の相互平均コンプライアンス $c_{k 1}(t)$ で予測した予測值 $\overline{d p}(t)$ を青破線で示す. 図 8 が示すように, 実際の応答の変化量 $\mathrm{d} p_{1}(t)$ と予測值 $\overline{d p}{ }_{1}(t)$ はよく一致しており, 時間領域の 相互平均コンプライアンスを中心差分法で求めることで, 系の非線形性も考慮できることを確認した. 


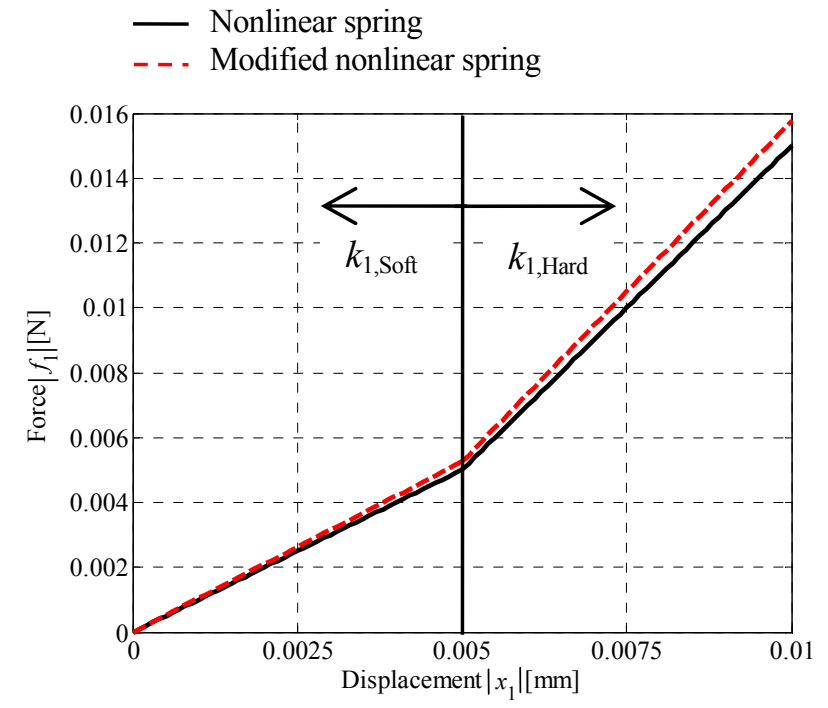

Fig. 6 Relationship of force and displacement of nonlinear spring. Black line indicates initial nonlinear spring. Red dash line indicates modified nonlinear spring.

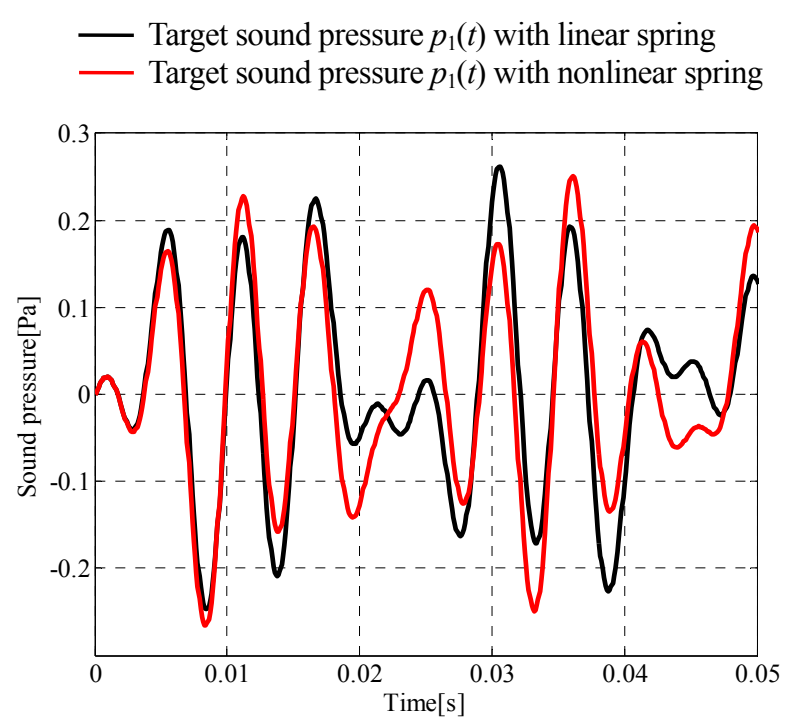

Fig. 7 Target sound pressure of linear system and nonlinear system. Black line indicates the response $p_{1}(t)$ of linear system. Red line indicates the response $p_{1 \text {, nonlinear }}(t)$ of nonlinear system.

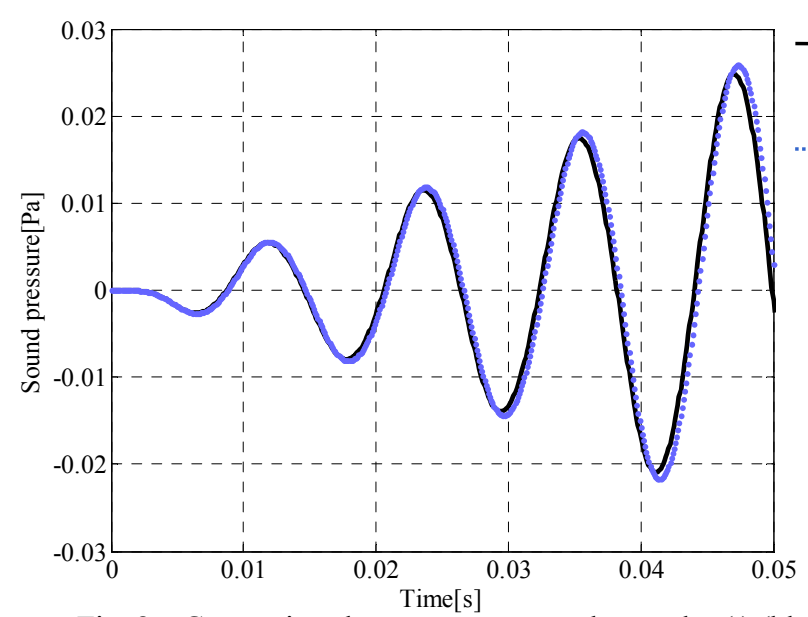

$\mathrm{d} p_{1}(t)$; Response change at acoustical node 1

$=$ response of modified structure $p_{1}^{\prime}(t)-$ original structure $p_{1}(t)$ $\overline{d p}_{1}(t)$; Estimated response change by time domain $c_{k 1}(t)$ $=-1 \times c_{k 1}(t) \times \mathrm{d} k_{1}$

Fig. 8 Comparison between response change $\mathrm{d} p_{1}(t)$ (black line) and the estimated response change $\overline{d p}_{1}(t)$ by time domain $c_{k 1}(t)$ (blue dot line) in the case of nonlinear system. These lines overlap each other, it indicates that time domain mutual mean compliance is also effective in nonlinear system.

\section{$4 \cdot 4$ 時間領域の相互平均コンプライアンスの特徵}

前章で示した時間領域の相互平均コンプライアンスの定式化と，本章の基礎検討の結果から時間領域の相互平 均コンプライアンスは以下の特徵を持つことがわかる.

・系を構成する各要素の時間領域の相互平均コンプライアンスの和は時刻歴の着目応答と等しくなることから， 時間領域の相互平均コンプライアンスは時刻歴の着目応答に対する寄与を表す．また時間領域の相互平均コン プライアンスは, 設計変数 $\alpha$ の変化に対して特性行列が $\alpha$ 割変化すると仮定したときの時間領域の感度に一 1 を 乗じたものと等しい. よって寄与と感度の両方の性質を持つ. 相互平均コンプライアンスの単位は対象とする 応答と等しいため, 板厚や密度, 構造系や音響系など異なる次元の感度も単純に比較することが可能である. この利点は周波数領域での相互平均コンプライアンスと同様である.

・線形性が成立する系において周波数領域の相互平均コンプライアンスを逆フーリエ変換したものと，中心差分 法で求めた時間領域の相互平均コンプライアンスは等しくなる. 周波数領域の相互平均コンプライアンスは各 
部品に生じる内力と各部品から着目自由度点までの伝達関数の積で表されることから, 時間領域の相互平均コ ンプライアンスは部品に生じる内力と各部品から着目自由度点までの伝達関数の積を逆フーリエ変換したもの という物理的な意味を持つ.

- 周波数領域の相互平均コンプライアンスは定常応答に対しての寄与であり, 周波数領域の相互平均コンプライ アンスを逆フーリエ変換して求めた時間領域の相互平均コンプライアンスは, 自動車の突起乗り越しなどブッ シュやサスペンションの非線形性までを考慮する問題への適用が困難である. 一方, 中心差分法で求めた時間 領域の相互平均コンプライアンスでは，ばねが振幅依存性を持つような非線形性も考慮可能である。 これは周 波数領域の相互平均コンプライアンスを単純に逆フーリエ変換し, 時間領域へ変換するだけでは達成されない.

\section{5. 有限要素モデルへの適用}

本章では中心差分法で求めた時間領域の相互平均コンプライアンスを自動車の簡易車体モデルへ適用し, 軽量 化と音圧低減を両立する構造変更を検討する.

\section{$5 \cdot 1$ 解析モデル}

解析対象の車体モデルを図 9，10 亿示寸．車体はタイヤ-サスペンションを模擬した 4 つのばねで支持されてい る. 力の入力点は前部サスペンション取り付け位置とし, 音圧評価点は図 10 に示すように車室内の運転者耳位置 とする. 図 11 に示した衝撃力を与えたときの 0 秒から 0.1 秒までの評価点音圧の時刻歴応答を図 12 に示す. 時 刻歴応答解析の時間刻みは $\mathrm{d} t=0.0001$ 秒とした. 時刻 0.069 秒に音圧のピークが確認できる.

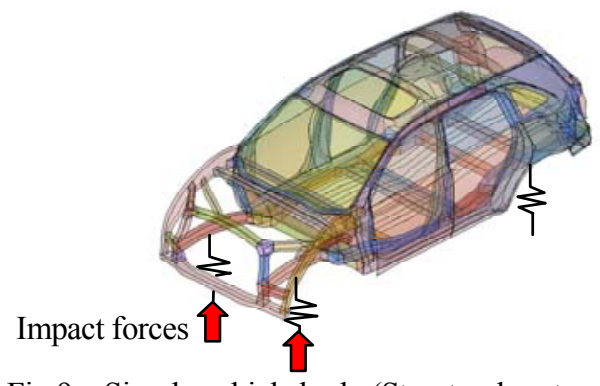

Fig.9 Simple vehicle body (Structural system) and impact forces. Impact forces are applied to the front suspension mounting positions.

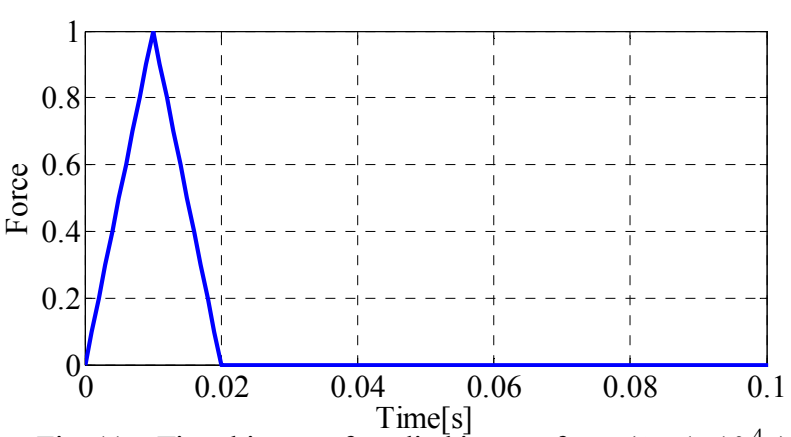

Fig. 11 Time history of applied impact force $\left(\Delta t=1 \times 10^{-4} \mathrm{~s}\right)$.
Sound pressure evaluation point

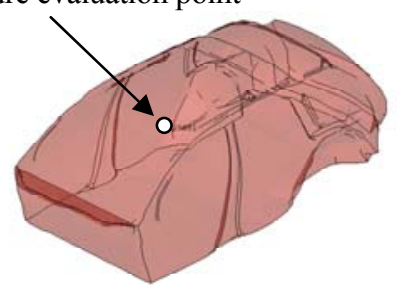

Fig. 10 Simple vehicle cabin (Acoustical system) and evaluation point. Evaluation point is selected as the driver's ear position

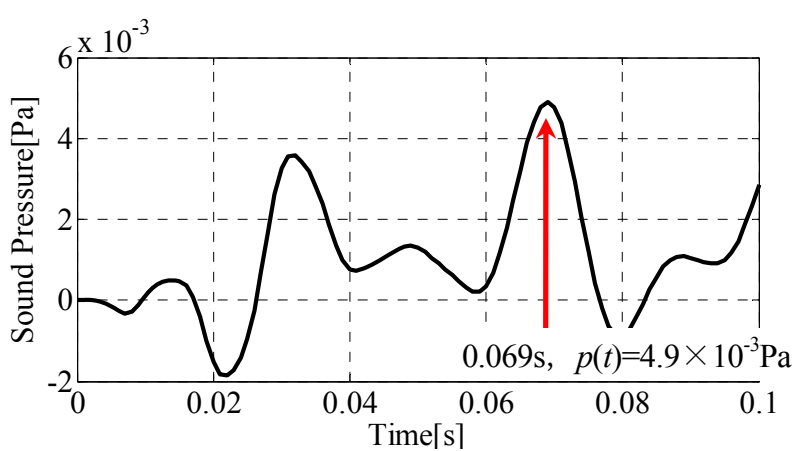

Fig.12 Transient sound pressure response at evaluation point of the original system. The curve has a peak at 0.069 s. 


\section{$5 \cdot 2$ 構造系，音響系，連成の寄与と感度}

図 12 に示した評価点音圧に対する構造系部品，音響系，連成の相互平均コンプライアンス，すなわち寄与と感 度を段階的に算出する. 音圧を低減する時刻は音圧のピークである 0.069 秒とする. 構造系は図 13 に示すように パネル系とフレーム系に分離する. 図 14 に評価点音圧 (黒線)，その音圧に対するパネル系 (赤線)，フレーム系

(青線), 音響系 (紫線), 連成 (緑線) の相互平均コンプライアンスを示す. 図 14 に示すように 0.069 秒ではパ ネル系の相互平均コンプライアンスよりもフレーム系の相互平均コンプライアンスが大きく，フレーム系への対 策が有効であることがわかる. また本来は構造系, 音響系, 連成の相互平均コンプライアンスを比較することで, 構造系や音響系が原因となる音圧ピーク，または連成が原因となる音圧ピークを判断できると予測していたが， 本適用例では応答に対する連成の寄与の割合がどの時刻でもほぼ等しくなった. 次節では 0.069 秒における相互 平均コンプライアンスが大きいフレーム部品に構造変更を施し，音圧の低減を図る.

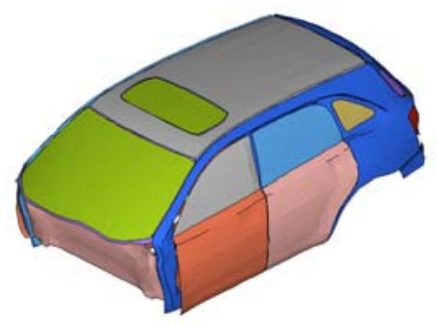

(a) Panel system

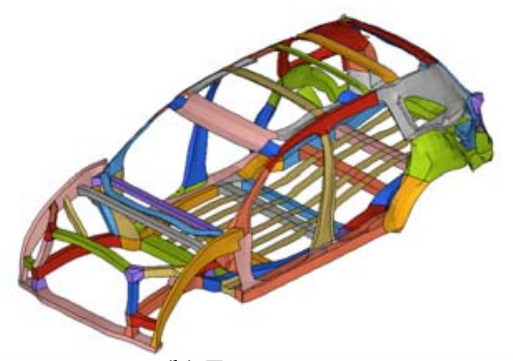

(b) Frame system

Fig. 13 Structural sub-systems of automobile body

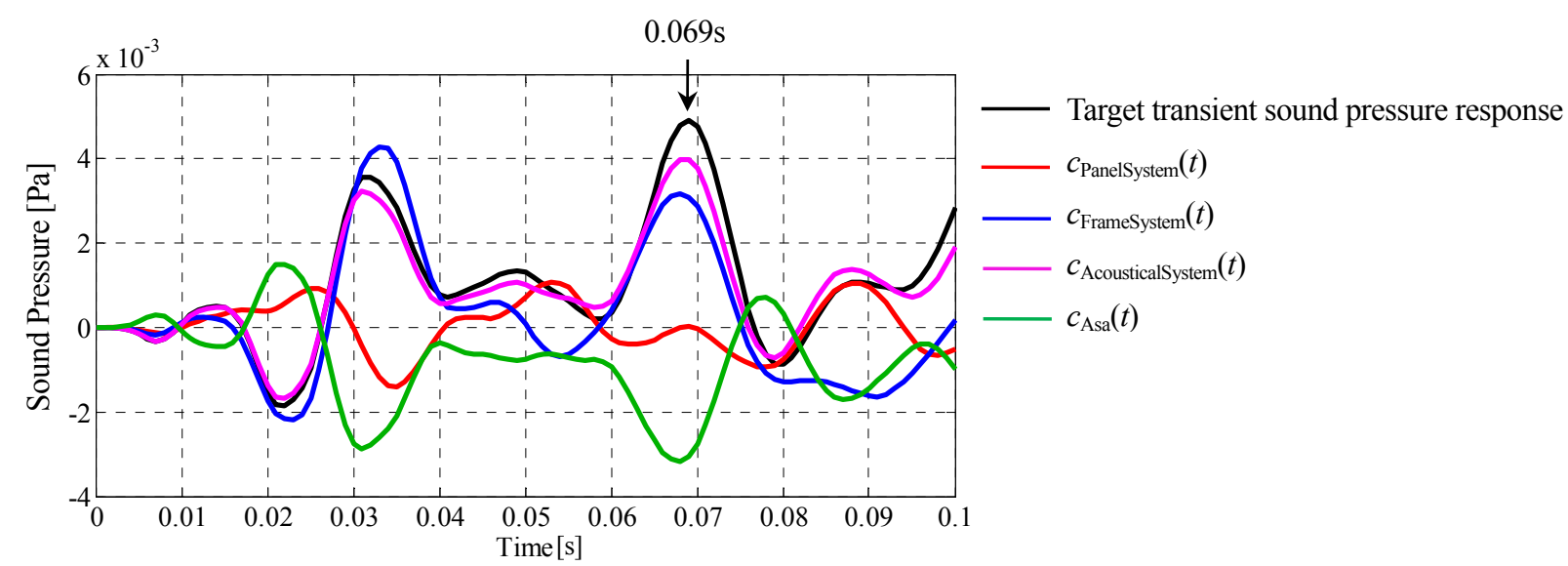

Fig. 14 Target transient sound pressure response (black line) and time domain mutual mean compliance of each component structure. At $0.069 \mathrm{~s}, c_{\text {FrameSystem }}(t)$ which indicates frame system sensitivity is larger than panel system's $c_{\text {PanelSystem }}(t)$, it implies that the structural modification to the frame is effective.

\section{$5 \cdot 3$ 音圧低減のための構造変更}

本節では 0.069 秒における音圧を低減するための構造変更を検討する. 0.069 秒においてフレーム系の中で相互 平均コンプライアンスが最も大きいフロアフレームと, パネル系の中で最も大きいフロアパネルの相互平均コン プライアンス，および，それらの相互平均コンプライアンスを質量と剛性の成分に分離した值を表 1 に示寸. 表 1 から相互平均コンプライアンスが最も大きい部位は, 図 15 に示したフロアフレームであり, その中でも質量の 成分が大きいことが確認できる.

音圧を低減するために相互平均コンプライアンスの大きいフロアフレームの質量を変更する. 質量の相互平均 コンプライアンスは負であるので, 質量を下げることで音圧を低減できる.ここではフロアフレームの密度を $5 \%$ 低減する. 図 16 に構造変更前の音圧応答 (黒線), 実際に構造変更を行った後の音圧応答 (赤線), 相互平均コン プライアンスによる予測值（青破線）を示す. 図 16 より相互平均コンプライアンスを用いることで応答の変化量 を予測可能であり，また質量の相互平均コンプライアンスが負である部品を選ぶことで，軽量化と音圧低減を両 立する効率的な構造変更が可能であることが確認できる. 
Table 1 Time domain mutual mean compliance $c(t)$ of dominant component structures at $0.069 \mathrm{~s}$.

\begin{tabular}{|c|c|c|c|}
\hline \multirow{2}{*}{$\begin{array}{c}\text { Component } \\
\text { structure }\end{array}$} & Mutual mean compliance of component structure & \multicolumn{2}{|c|}{$\begin{array}{c}\text { Mutual mean compliance divided to mass and } \\
\text { stiffness element of each component structure. }\end{array}$} \\
\hline \multirow{2}{*}{ Floor frame } & $\begin{array}{c}-1.40 \times 10^{-3} \mathrm{~Pa} \\
\text { (Normalized value by target response }=-28.5 \%)\end{array}$ & Mass & $-7.63 \times 10^{-3} \mathrm{~Pa} \quad(-155.8 \%)$ \\
\cline { 3 - 5 } & $-1.16 \times 10^{-3} \mathrm{~Pa}$ & Stiffness & $6.24 \times 10^{-3} \mathrm{~Pa} \quad(127.3 \%)$ \\
\cline { 3 - 5 } Floor panel & (Normalized value by target response $=-23.7 \%)$ & Stiffness & $-2.01 \times 10^{-3} \mathrm{~Pa} \quad(-41.0 \%)$ \\
\hline
\end{tabular}

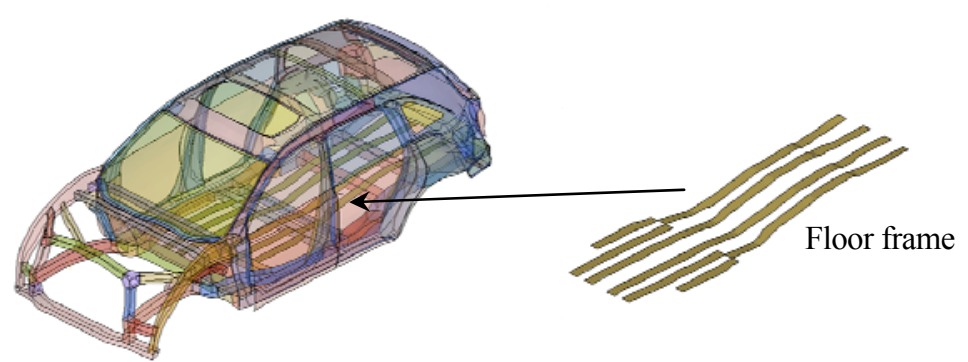

Fig. 15 Floor frame of simple vehicle body which has a large mutual mean compliance at 0.069 s. In structural modification, mass reduction of floor frame is applied to reduce the target transient sound pressure.

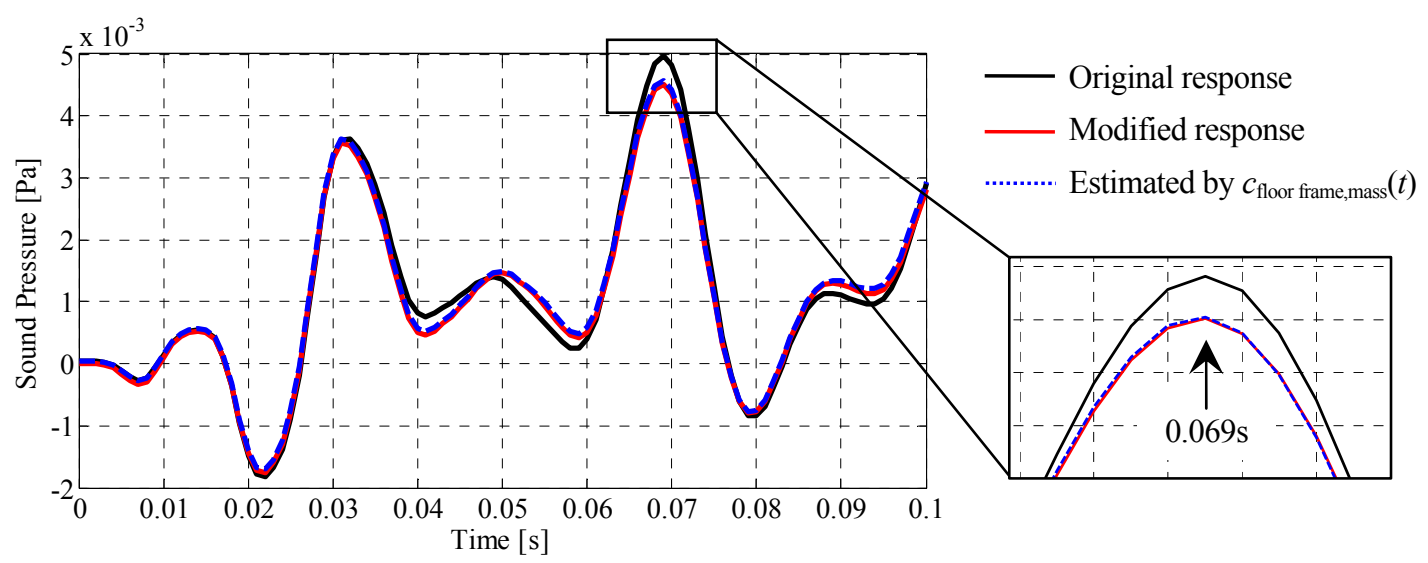

Fig. 16 Comparison of the responses of original structure (black line), modified structure (red line) and response estimated by mutual mean compliance of floor frame's mass component(blue dot line). The modified structure response and predicted response overlap each other, and it indicates validity of time domain mutual mean compliance.

\section{6. 結言}

本稿では自動車の突起乗り越し時の時刻歴音圧応答の低減を目的に，寄与と感度，両方の性質をもつ相互平均 コンプライアンスを時間領域へ拡張した．以下に得られた結果をまとめる.

・非線形系へも対応可能なように中心差分法を用いて時間領域の相互平均コンプライアンスを導出し，時間領域 の相互平均コンプライアンスが寄与と感度，両方の性質を持つことを理論的に示した。またばねが振幅依存性 をもつ非線形系へ適用し，時間領域の相互平均コンプライアンスを中心差分法で求めることで系の非線形性も 考慮できることを確認した.

・線形性が成立する系において周波数領域の相互平均コンプライアンスを逆フーリエ変換したものと，中心差分 法で求めた時間領域の相互平均コンプライアンスが等しいことを確認し，時間領域の相互平均コンプライアン 
スは部品に生じる内力と各部品から着目自由度点までの伝達関数の積を逆フーリエ変換したものという物理的 な意味を持つことを示した.

・簡易車体モデルに時間領域の相互平均コンプライアンスを適用し, 音圧への感度が高い部位と, その部位の質 量, 剛性の寄与を調べた。 そして相互平均コンプライアンスに基づいた対策により質量を低減しつつ音圧を低 減する効率的な対策の検討が可能であることを示した.

謝 辞

本研究を進めるにあたり解析モデルをご提供いただいた株式会社本田技術研究所の斎藤浩司様，相澤伸夫様に 感謝申し上げます.

\section{文献}

古屋耕平, 松村雄一, 多治見大樹, 斉藤浩司, 相澤伸夫, 相互平均コンプライアンスの構造音響連成系への適用, 日本機械学会論文集, Vol. 80, No.811 (2014), DOI:10.1299/transjsme.2014dr0053.

MSC Software, MSC nastran 2013 dynamic analysis user’s guide, transient response analysis (2013), pp.209-213.

村松英行, 馬場広樹, 神野紘二, 西山淳, 小林義明, ハーシュネス振動・過渡音予測技術, 自動車技術会学術講演前 刷集, No.8-11(2011), pp.19-22.

西脇眞二, Frecker, M. I., 関勝載, 菊地昇, 柔軟性を考慮した構造の最適化 : 第 1 報,定式化とコンプライアントメ カニズムへの応用，日本機械学会論文集 C 編, Vol. 63, No.612 (1997), pp.2657-2664.

高野賢太, 吉村卓也, 時刻歴感度に基づく構造変更予測に関する基礎検討, 自動車技術会学術講演前刷集, No.51-14(2014), pp.21-24.

田中裕之, 島田博, 和田靖彦, 手島聡, 須磨達也, 粐井秀斗, 突起乗り越し音解析予測および分析技術開発, 自動 車技術会学術講演前刷集, No.44-13(2013), pp.5-8.

鶴見康昭, 中川稔章, 山川宏, 忘答最小化問題の相互平均コンプライアンスによる寄与部位抽出法, 日本機械学会 論文集 C 編, Vol. 72, No.719 (2006), pp.2080-2087.

\section{References}

Furuya, K., Matsumura, Y., Tajimi, D., Saito, K. and Aizawa, N., Application of mutual mean compliance to vibro-acoustic system, Transaction of the JSME (in Japanese), Vol.80, No.811(2014), DOI:10.1299/transjsme.2014dr0053.

MSC Software, MSC nastran 2013 dynamic analysis user's guide, transient response analysis (2013), pp.209-213.

Muramatsu, H., Baba, K., Jinnno, K., Nishiyama, J. and Kobayashi, Y., Time domain analysis for interior acoustic response, JSAE Convention Proceedings, No.8-11(2011), pp.19-22(in Japanese).

Nishiwaki, S., Frecker, M. I., Min, S. and Kikuchi, N., Structural Optimization Considering Flexibility : 1st Report, Formulation of Equation and Application to Compliant Mechanisms, Transaction of the Japan Society of Mechanical Engineers, Series C, Vol.63, No.612 (1997), pp.2657-2664 (in Japanese).

Takano, K. and Yoshimura, T., Sensitivity analysis of time history response for structure modification, JSAE Convention Proceedings, No.51-14(2014), pp.21-24(in Japanese).

Tanaka, H., Shimada, H., Wada, Y., Tejima, S., Suma, T. and Momii, H., Development of prediction and analysis technology for impact noise, JSAE Convention Proceedings, No.44-13(2013), pp.5-8(in Japanese).

Tsurumi, Y., Nakagawa, T. and Yamakawa, H., A new method of selecting effective parts for minimizing a target response using mutual mean compliance, Transaction of the Japan Society of Mechanical Engineers, Series C, Vol.72, No.719(2006), pp.2080-2087(in Japanese). 